University of Rhode Island

DigitalCommons@URI

Open Access Dissertations

1989

\title{
Relationships Between Communication Style Variables and Sales Effectiveness
}

Elaine M. Notarantonio

University of Rhode Island

Follow this and additional works at: https://digitalcommons.uri.edu/oa_diss

\section{Recommended Citation}

Notarantonio, Elaine M., "Relationships Between Communication Style Variables and Sales Effectiveness" (1989). Open Access Dissertations. Paper 1024.

https://digitalcommons.uri.edu/oa_diss/1024

This Dissertation is brought to you for free and open access by DigitalCommons@URI. It has been accepted for inclusion in Open Access Dissertations by an authorized administrator of DigitalCommons@URI. For more information, please contact digitalcommons-group@uri.edu. 
RELATIONSHIPS BETWEEN COMMUNICATION STYLE VARIABLES AND SALES EFFECTIVENESS

BY

ELAINE M. NOTARANTONIO

A DISSERTATION SUBMITTED IN PARTIAL FULFILLMENT OF THE REQUIREMENTS FOR THE DEGREE OF DOCTOR OF PHILOSOPHY

IN

PSYCHOLOGY

UNIVERSITY OF RHODE ISLAND

1989 


\section{ABSTRACT}

This research involves two studies which investigated the relationship of communication style variables with effective sales performance. Norton's (1978) communication style construct was used as a guiding framework.

Study 1, examined 74 real estate agents' self-reports of communication style, performance and general sales practices used. In addition, objective measures of respondent's performance were obtained from company records.

A stepwise regression analysis revealed the construct of precise as the only significant predictor of income. A step-wise discriminant analysis showed that the constructs of precise and impression-leaving were significant discriminators among groups of salespeople who were categorized based on income.

A cluster analysis was also performed. The three cluster solution was followed-up by a discriminant analysis. The discriminant analysis described two distinct sales types based on different combinations of the communicator style variables. The variables in the first discriminant function were labeled as "strong" while those in the second function were labeled as "casual".

The main finding from this study, however, was that precise was strongly associated with effective sales performance in a real estate organization. 
Study II empirically tested whether or not different combinations of the precise and friendly subconstructs affect sales effectiveness.

It was hypothesized that the more Precise a salesperson was, the more effective the individual would be in selling the product. It was also hypothesized that the more Friendly the salesperson was the more effective $s /$ he would be.

Four groups of students saw videotapes of a sales interaction. Each tape depicted one of four combinations of high and low levels of Preciseness and Friendliness. Subjects viewed the tape $(n=112)$ after which they completed a 40-item questionnaire. Separate three-way ANOVAS for each measure were run with Friendly, Precise, and sex as independent variables for the communicator style measures and other selected items.

The results of this study point to precise not being positively associated with sales effectiveness. However, as in study $I$, the results do indicate that communication style variables which can be perceived as 'strong' are related and it is again suggested that by "blending" different combinations of variables together different pictures emerges.

Directions for future research are also discussed. 


\section{ACKNOWLEDGEMENT}

I would like to thank and acknowledge the many individuals who supported and guided me not only during the preparation of this dissertation but throughout the entire Ph.D. program.

Dr. Jerry L.Cohen, my major professor recognized the major hurdles that I needed to overcome in order to complete this program within a particular time period. His committment and support to me in meeting my various deadlines required him to go far beyond what his responsibility would require. At the same time his highest standards were never compromised.

Dr. Paul Florin and Dr. Greg Lessne, were also very supportive and committed to me. They were always available, day or night, to answer questions and to provide direction.

A special recognition goes to Dr. Charles Collyer who believed in me from when I first applied to the Ph.D. program.

Finally, I thank my family. My husband, Ralph Charello for being my backbone during this program; my son, Derek. Charello for understanding why I couldn't be there for him; my son, Evan Charello, for coming along in the middle of all this; and my parents, Mr.\& Mrs. Notarantonio for every kind of support. 
Approval page---- Page

Abstract-- $---1-0-1$ i

Acknowledgements--

List of Tables--

Introduction and Backround------

Method - Study 1-- -

Subjects--- - - - - - - - - - - - - - - - - - - - - - - - - - - - 13

Materials------- - - - - - - - - - - - - - - - - - - - - 14

Results----- - - - - - - - - - - - - - - - - - - - - - - - - - - 16

Discussion-------- - - - - - - - - - - - - - - - - - - - - - - - - 21

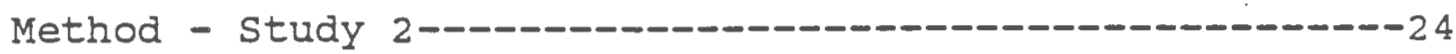

Subjects-- - - - - - - - - - - - - - - - - - - - - - - - - - - - - - - 26

Apparatus------



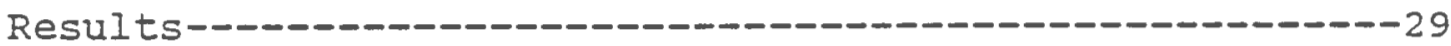

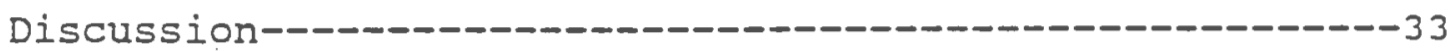

Future Research---- - - - - - - - - - - - - - - - - - - - 36

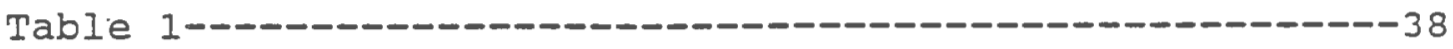

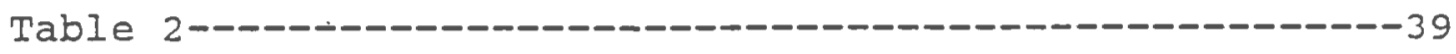

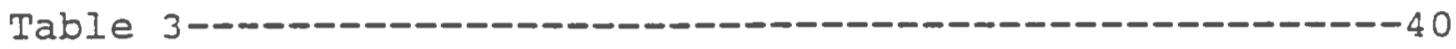

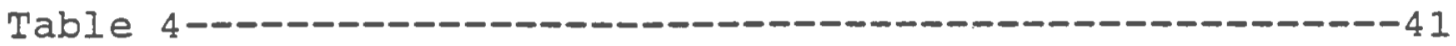

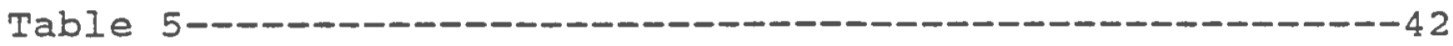

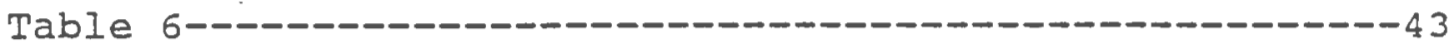


Table $7-0-14$

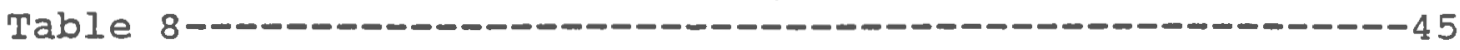

Table 9--D-

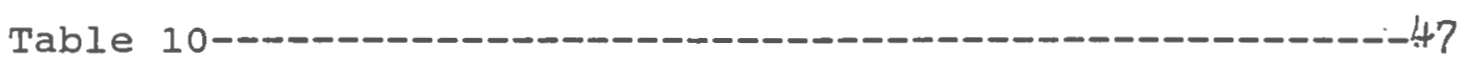

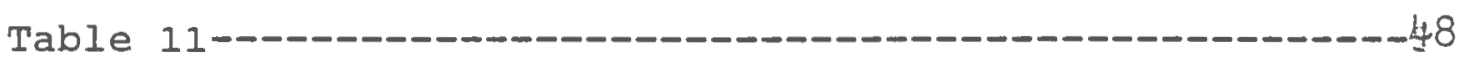

Table 12---

Table 13--

Table 14---_-

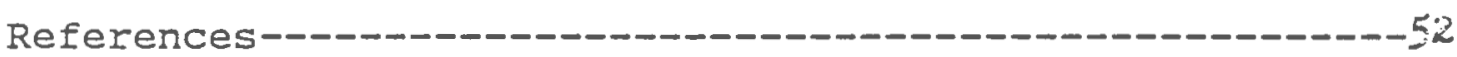

Appendix A--

Appendix B----

Appendix C--

Appendix D--

Bibliography-- 


\section{LIST OF TABLES}

1. Means and Standard Deviations for Questionnaire items-----38

2. Pearson Product Moment Correlations for CSM'S----------- 39

3. Beta Coefficients for stepwise regression CSM'S--------- 40

4. Means and Standard Deviations for Clusters----------------41

5. F-Ratios and Discriminant Function Coef. Cluster Analy.---42

6. Pearson product moment correlations precise and practice--43

7. Beta coefficients for regression for Sales Practice-------44

8. Pearson Product Moment Correlations Lab study------------45

9. Significant findings for ANOVAS----------

10. Cell Means for Dominance in precise $x$ friendly inter.----47

11. Cell Means for Monopolize in interaction--

12. Cell Means for strained in interaction---------------49

13. Cell Means for Sales type interaction--

14. Cell Means for liklihood of buying interaction---------- 51 
Relationships Between Communication Style Variables and Sales Effectiveness

Norton (1978) has established a foundation for a communicator style construct. He defines communicator style as the way in which a person verbally and paraverbally interacts to signal how literal meaning should be taken, interpreted, filtered or understood. He operationally defines the communicator style domain in terms of ten independent variables and one dependent variable. The independent variables or subconstructs are: impression-leaving, (2) contentious, (3) open, (4) dramatic, (5) dominant,

(6) precise,

(7) relaxed,

(8) friendly, attentive, and (10) animated. The dependent variable, also a subconstruct, is communicator image and is included in the domain as an overall assessment of communicator ability. Communicator style is assumed to be different from personality in that it can be deliberately manipulated by the communicator (Norton and Nussbaum 1980).

Two primary lines of research have produced substantial empirical evidence for the reliability and validity of the communicator style construct (Bednar, 1982). One has focused upon the detailed analysis of each of the components which comprise the style domain. To date, four of these have been explicated in some detail: the dramatic (Norton, 
Sypher, clarke and Brady, 1977; Norton, Baker, Bednar, Salyer, and McGough, 1978), the open (Norton and Montgomery, 1979), the relaxed (Emery, Norton and Plain, 1980), and the attentive (Norton and Pettegrew, 1977).

The second line of research has focused upon relationships between communicator style and various perceptual processes and interpersonal consequences. Some topics that have been addressed include: teacher effectiveness (Norton, 1977; Norton and Nussbaum, 1980), dyadic perception of communicator style (Norton and Miller, 1975), the personnel selection interview (Norton and Bednar, 1979; Norton and Robinson, 1980), communicator style as an effective determinant of attraction (Norton and Pettegrew, 1977), sex differences in self-reported communicator style (Norton and Montgomery, 1979, staley and Cohen, 1988), and communicator style and managerial performance (Bednar, 1982). All of these studies are characterized by the use of Norton's construct as a guiding framework.

In the selling process, exchange is typically initiated, maintained and terminated on a person-to-person basis. The salesperson's most basic activity during this exchange is communication. In the competitive marketplace, effective communication is of paramount importance: Along these lines, it is no exaggeration to say that the salesperson is the most important communicator in the entire organization. All other efforts are of no avail if the salesperson is unable to 
communicate in a manner that induces purchase. For the firm to achieve full promotional impact in the marketplace, the salesperson must be an effective communicator. Insight into the communication process is therefore of vital importance. In spite of this, communication has received little attention in personal selling research (Capon, Holbrook, and Hulbert, 1977).

Although there have been many studies which have examined the determinants of sales effectiveness, very few look at communication style. Most of the early empirical work related to personal selling examined the personal characteristics of the salesperson. Several later studies have examined communication content followed by communication code, rules and to some extent style.

Churchill, Ford, Hartley and Walker (1985) conducted a meta-analysis to analyze the evidence in the literature about the factors that affect salesperson performance. The authors obtained 1653 observations of correlations between predictor and performance criteria. Given the large number of factors that have been investigated as possible determinants of a salesperson's performance, the authors categorized the correlations using the Churchill, Ford, and Walker (1985) model of salesperson performance. Their model holds that salesperson performance is a function of five basic factors: (1) aptitude, (2) skill level, (3) motivation, (4) role perceptions, and (5) personal, organizational, and environmental variables. The 
results of this analysis show that the determinants rank as follows: (1) personal factors, (2) skill, (3) role variables, (4) aptitude, (5) motivation, and (6) organizational/environmental factors. Another conclusion was that none of the predictors by themselves accounted for a great amount of the variation in performance - less than $10 \%$ on the average. Finally, the results indicate that the strength of the relationship between the major determinants and salespeople's performance is affected by the type of products salespeople sell.

Weitz (1981), Friedman \& Churchill (1987), and Szymanski (1988) discuss the importance of the degree of adaptiveness of salespeople when selling to clients. In this sense, adaptiveness is defined as "choosing the selling strategy that best meets the needs of the consumer" (Weitz 1981). The authors are specifically referring to the salesperson's ability to categorize subjects accurately at each stage of the sales process, that is, to engage in a qualification process at each stage. By properly qualifying the prospective client into the appropriate selling strategy category, the salesperson can access and apply the influence approach that maximizes the probability of a sale.

Past research efforts have attempted to uncover universal characteristics or behaviors that enable salespeople to perform successfully across a wide range of situations. Interactions between sales behaviors and aspects of the sales situation have 
not been considered. Weitz (1981) contends that salespeople have the opportunity to match their behavior to the specific customer and situation they encounter. They can consider each interaction individually and present themselves and their product so as to be maximally effective in that interaction. In some interactions salespeople might find it more advantageous to present themselves as similar to their customers, while in other interactions salespeople might find it more advantageous to be perceived as an expert. This suggests that perhaps the ability to adapt one's presentation to the needs of the situation might be related to sales effectiveness.

Weitz, sujan and sujan (1986) provide a framework for research directed toward increasing understanding of the ability component of sales performance. The framework also centered on the specific ability to adapt sales behaviors effectively to the demands of the sales situation. These authors define adaptive selling as " the altering of sales behaviors during a customer interaction or across customer interactions based on perceived information about the nature of the sales situation." However, the framework focuses upon adaptation of content, not style. The authors believe that ability related to adaptive selling is a crucial aspect because it indicates the degree to which salespeople are able to take advantage of the unique communication elements associated with personal selling. Salespeople have the 
opportunity to do "market research" on each customer and implement a sales presentation that is maximally effective for that customer. In addition, salespeople observe the reactions of their customers to sales messages and make rapid adjustments (Weitz \& wright 1978). It should be noted that the authors' framework for adaptive selling focuses on manipulation of the sales presentation content as opposed to style. Nevertheless, they recognize the importance of adaptive selling as an overall strategy.

In marketing, most studies that have considered communication style have done so indirectly. one recent exception is a study conducted by Notarantonio and cohen (1988). This study empirically tested whether or not different communication styles affect perceptions of sales effectiveness using the open and Dominant styles from Norton's (1978) dimensions. Four groups of students saw videotapes of a sales interaction. Each tape depicted one of the four combinations of high and low levels of Dominance and Openness. The experiment involved subjects viewing the tape after which they completed a 42-item questionnaire. Six composite scores were identified from groups of questions that were a priori related. Four of these composite measures showed significance; perceptions of the product being sold, the interaction between the salesperson and customer in the tape, probability of purchase of the product in the tape and perceptions of the salesperson being depicted in the tape. 
Respondents, in general, rated the high Dominant/low Open and low Dominant/high open conditions more favorably than the high Dominant/high open or low Dominant/low Open. Notarantonio and Cohen (1988) provided some preliminary evidence for the use of Norton's style dimensions as predictors of sales effectiveness. Another finding from this study that is of notable importance is the finding of significant interactions between the Openness and Dominance dimensions. One of the points made in this study that is relevant to the present research was that by "blending" various combinations of the Open and Dominant variables a different picture emerged in terms of how a communicator was perceived as opposed to how a communicator would have been perceived based on either dimension separately. As mentioned earlier, communication style is something that can be deliberately manipulated by the communicator (Norton, 1978). It appears that in manipulating his/her style, the communicator, rather than to turn one dimension "off" while turning the other "on", tends to use different combinations of the variables such as was demonstrated with the high Dominant/low open and low Dominant/high open combinations. To use an analogy, it is not unlike the adjusting of an equalizer on a stereo component system.

Pace (1962) examined the relationship between oral communication and sales effectiveness. Specifically, the study attempted to identify the attributes of oral 
communication that reliably distinguished between the selling behavior of the "better" and "poorer" salespeople. Two equitable groups of salespeople were differentiated into a more effective "high" group and a less effective "low" group by means of a Sales Effectiveness Index (SEI) and were compared in terms of selected aspects of their communication behavior. The SEI criterion was computed by dividing the net dollar value of sales by hours devoted to active selling. Each of the subjects was rated on six separate factors of oral communication (voice, language, bodily behavior, listening, personal attitudes, initial impression, and on a "gestalt" or overall impression. These factors are relevant to Norton's communicator style variables in that (1) each of the ten independent variables of Norton's measure are, in part, based upon the same six factors that were used in the Pace (1962) study and (2) Just as Pace used an overall rating, so does Norton refer to the dependent variable or eleventh subconstruct as "communicator image". The results showed that the more effective salespeople were rated higher than the less effective ones in terms of overall impression of communication. Pace suggests that oral communication skill is likely to be a reliable criterion for differentiating superior from inferior salespeople. Also, sales methods such as using "emotional appeals" and "dramatizing" distinguished between the more effective and the less effective salespeople. These methods seem to be analogous to Norton's animated and dramatic style dimensions. 
It is interesting to note that, in the Pace (1962) study, ratings of salespeople on separate skills - taken one at a time- failed to distinguish between the more effective and the less effective salespeople. The general implication from this study is that salespeople who are less effective in basic oral communication skill will also be less effective in utilizing the more specialized aspects of persuasive communication. The Notarantonio and Cohen (1988) study described earlier, provides additional support for the use of Norton's communicator style measure as a measure of sales effectiveness.

Sheth (1976) suggests a paradigm where customers and salespeople can be characterized according to their communication styles as task-oriented, interaction-oriented or self-oriented. Sheth's conceptualization of the customer/salesperson communication style is based on a framework of leadership style suggested by Bass $(1960,1967)$.

Williams and Spiro (1985) conducted an exploratory study which first developed scales to measure the communication style variable in personal selling and then tested whether the styles affected sales outcome. Williams and Spiro draw on Sheth's (1976) model; the scale items developed were more specific to the sales interaction context than those from the general Bass inventory.

The results of the Williams and spiro (1985) study show that communication styles as measured by task, self and interaction orientation were significant in terms of 
explaining sales variance. This finding supports the notion that communication style be considered as one of the dimensions affecting sales outcome. Furthermore, since communicator style is something that is assumed to be deliberately manipulated by the communicator; it is postulated that, in a sales situation, a salesperson can manipulate his/her style to provide for maximum sales effectiveness.

It is possible that one of the distinguishing characteristics of those salespeople who are high performers is that they are able to manipulate their communication style during a sales interaction, or at least recognize the need to do so. That is, perhaps the high performers are successful because they are able to recognize what style a particular sales situation requires and they so manipulate their own style. This contention can be supported by Williams and spiro (1985). They state that, "...perhaps the successful salesperson is one who recognizes different customer [types] and adapts his or her communication style appropriately to interact with the customer" (p.440).

Further evidence for the distinction in communicator styles between "high" and "low" groups can be found in a study by Norton and Pettegrew (1977). This research investigated whether an effect could be found between communicator style components and attraction. Two conditions were studied. In the first condition, people were asked to respond to the 
questionnaire with the person they liked best in mind. In the second condition, people were asked to respond to the questionnaire with the person they liked least among their acquaintances in mind. Two measures were used; an attraction measure, and a communicator style measure. The results show that communicator style variables appear to be strong covariates of attraction variables. The authors also found that a particular domain of communicator style variables recurrently emerge as best predictors of attraction. They are attentive, friendly and relaxed. The authors are also quick to point out that the characteristic influencing attraction may be mediated by context, situation and time.

Bednar (1982) examined the degree to which perceived communicator style characteristics of organizational managers and supervisors co-varied with their performance. Generally, the results of this investigation indicated that communicator style was significantly associated with different levels of managerial performance. Another major finding of this investigation was that perceived communicator style characteristics, associated with managerial performance, changed across self, superiors, subordinates and peer levels of perception. This finding reinforces the contention made by Norton and Pettegrew (1977) that style characteristics may be mediated by context, situation and time.

Based upon this body of literature, the researcher thought that it might be interesting to examine a group of salespeople 
in an organization to see if there are any common link among those who are effective as opposed to those who are less effective performers. The present research attempts to examine some of the factors that characterize real estate salespeople in terms of communication style and in terms of other variables. Real estate salespeople were chosen for a number of reasons. The purchase of a home is a major one and purchasers tend to place their trust into the hands of a real estate agent. In essence a relationship develops between buyer and agent. It is the agent who will search the market for the type of home that is suitable for the client, as well as to keep the client apprised of any new market developments. If a client is not pleased with the agent's performance the relationship is usually terminated a new agent is sought. Communication therefore is central to maintaining this relationship. This study is an exploration of what the potential differences and similarities are among top performing salespeople and those who are poorer performers in terms of communication style as measured by Norton's (1978) communicator style instrument (See Appendix A for descriptions of the eleven measures). The researcher also examined respondents' self-reports regarding perceptions of their own performance and sales practices relevant to communication style. It was hoped that some insight would be gained as to which communicator style and sales practice variables describe and discriminate among salespeople in terms of their 
performance as well as which variables might be predictive of successful sales performance.

Finally, in order to gain more insight into the relationship between the variable(s) which emerge(s) from this study and sales effectiveness, a controlled laboratory situation was set-up to manipulate these variables. The purpose of this research was not to determine how salespeople should communicate in order to be effective; rather it was to identify and describe communicator style characteristics and other general sales practices which may be associated with independent criteria of sales performance.

$$
\text { Study } 1 \text { - Method }
$$

\section{Subjects}

Subjects for the field study consisted of salespeople from a regional Real Estate organization. From an initial pool of 300 subjects, 59 responses were received of which 55 questionnaires were usable. A second plea was made to nonrespondents. This resulted in 26 additional returned questionnaires. Of these, only 15 were usable. The remaining 11 were not usable because the respondents were new to the company and had not made any sales so therefore could not provide dependent measures (income and company profit). A total of 74 usable questionnaires resulted.

of those that responded, $77.5 \%$ of the subjects indicate that some of their sales training has included communication style, $85.9 \%$ work full-time, with $66.2 \%$ of respondents 
indicating that they work more than 31 hours per week. In addition, $57.7 \%$ have been working for the company for more than 2 years.

\section{Materials}

Subjects were asked to complete a questionnaire which included three types of items (see Appendix B). The first set of items were Norton's (1978) communicator style self-measure short form. All questions on this scale ranged from 1 (strongly agree) to 7 (strongly disagree). The second set of questions was developed by the investigator and were identified as: (1) the respondent's perception of him/herself (PER), (2) whether the respondent thinks that communication style is something that can be deliberately manipulated (MANIP), (3) whether the role of communication style is important in making a sale (IMP), (4) self-rating of sales performance within company (SELF), (5) whether respondent's communication style is different with a client than it is on a general basis (DIFF), (6) whether the respondent changes communication style when interacting with different clients (CHANGE), (7) the extent to which the respondent's sales training has included an understanding of communication style (TRAIN), ( 8 ) the average length of time it has taken the respondent to enter into a sales agreement (SALES), (9) whether the respondent works full-time or part-time (WORK), (10) how many hours per week the respondent works (HOURS), (11) time working for the company (LONG), and (12) units sold within the 
past year (UNITS). The items which make up this scale are referred to as 'sales practice' variables for purposes of discussion.

In order to check for "test distortion", the MarloweCrowne Social Desirability scale (Crowne \& Marlowe, 1960) was included as the third set of items.

This scale was included to determine whether subjects were responding to the questionnaire items in a way that they saw as 'appropriate' or in a way that would make them 'look good'. Respondents were asked to identify themselves on the questionnaire so that the researcher could then obtain income information about each individual from the company's vicepresident. Subjects were asked to read and sign an informed consent form (see Appendix B).

The participating company agreed to provide sales performance data on each of the respondents. Performance was measured by a dollar income amount for each individual as well as contribution to company profit. These are industry-wide standard measures of performance.

The two performance measures of sales effectiveness were transformed to the mean monthly contribution to company profit (Copro) and the mean monthly earnings (Income).

The questionnaires were given to the participating company's sales managers who, in turn, distributed the questionnaires at a weekly sales meeting. 
Results

This section begins with a discussion of the questionnaire items. We first examine some of the descriptive measures, followed by Pearson product moment correlations, multivariate discriminate analysis and finally cluster analysis.

one would first want to turn attention to some of the descriptive measures so that the responses for this group of 74 subjects as a whole can be examined. As can be seen in Table I which presents complete summary statistics for the three item sets, most respondents consider themselves to be a friendly communicator $(\underline{M}=1.548)$ and not a contentious communicator $(\underline{M}=4.514)$. Respondents also saw themselves as attentive $(\underline{M}=2.03)$, as possessing a good communicator image $(\underline{\underline{M}}=2: 03)$, as impression-leaving $(\underline{\mathrm{M}}=2.58)$, as relaxed $(\underline{\mathrm{M}}=$ $2.60)$ and to a lesser extent animated $(\underline{M}=2.70)$ and precise ( $\underline{M}$ $=2.88)$. The subconstructs of Dramatic $(\underline{M}=3.45)$ and open $(\underline{M}$ $=3.42$ ) are approaching the neutral point on the scale. It is also interesting to note that, with the exception of contentious, none of respondents indicated disagreement with any of the other communicator style measures. Of the ten communicator style measures, contentious appears to be the only one with a negative connotation.

Respondents indicate that there is some recognition of communication style as a relevant strategy for a sales situation in response to the question of whether communication 
style is important for making a sale $(\underline{M}=1.64)$.

In order to assess the relationships among the variables, Pearson product moment correlation coefficients were calculated. As can be seen in Table 2, measures of individual sales performance (income, company profit and units sold) are highly related to each other. This interrelationship was expected since these variables all seem to be measuring the same thing. Therefore, income will be used as the sole measure of sales effectiveness for the remainder of this study. The only communication style variable that was significantly related to income was precise $(r=.308)$. Precise was also significantly related to company profit $(r=.3618)$. The correlations also show that the dominant, dramatic, animated, contentious, friendly and impression-leaving subconstructs were significantly correlated as well as the friendly, attentive, and relaxed subconstructs. In order to better understand how these communicator style variables were related to income, a forward stepwise regression analysis with Income as the dependent measure was performed with the ten communicator style variables. The only variable that was entered into the equation was precise with an $R^{2}$ of $.106, \underline{F}(1,68)=8.075$, $\mathrm{p}<.01$. See Table 3 for beta weights and significance levels.

Respondents were then trichotomized into three groups, low, middle and high, according to their sales performance as indicated by income level. In order to assess which combinations of the subconstructs would best distinguish among 
these groups, a discriminant analysis was performed on the communicator style variables. Of the ten communicator style variables, two emerged as discriminating among the three groups; Precise and Impression-leaving. Although neither of the two emerging functions was significant, the first function was marginally significant with a $x^{2}(4)=8.205, p>05$. Precise loads highest on the second function and loads in a negative direction on the first function. Group 1, the high performers, is lower on function 1 than function 2. Application of these functions classified $45.8 \%$ of the cases correctly. This analysis indicated the precise communication style variable was the best discriminating variable among the groups.

In order to gain a better understanding of these 74 sales agents in relation to communication style, and to obtain an alternative way of viewing these subjects, a cluster analysis using Ward's (1963) method was performed. The three cluster solution was then analyzed using a step-wise discriminant function anaiysis to identify the subconstructs which contributed to distinguishing among the three clusters. The two discriminant functions were found to be significant, $x^{2}$ $(16)=172.69, p<.001$ and $x^{2}(7)=75.670, p<.001$, with canonical correlations of .8849 and .8344 . The means and standard deviations for the three cluster solution across the ten subconstructs of the communicator style measure are presented in Table 4. The standardized discriminant function 
coefficients are presented in Table 5. Using these discriminant functions, it was possible to correctly classify $97.1 \%$ of the individuals as to communicator style. The first function shows that salespeople who are more impressionleaving, attentive, precise, open and relaxed than the others are falling together. A second function reveals individuals who are more animated, dramatic, dominant, friendly and contentious than the others.

In addition to looking at the ten communicator style variables, the researcher also examined the self-report responses of general sales practice variables. Examination of these variables provides a clearer picture of respondents' understanding and use of the concept of communication style. The descriptive information presented in Table 1 indicated that there was some recognition on the part of respondents that communication style is a relevant strategy for a sales situation. The importance of communication style in making a sale was recognized by $94.5 \%$ of the respondents, with a mean response of 1.644. Communication style is different when interacting with clients than it is on a general basis at least some of the time for $53.5 \%$ of subjects $(\underline{M}=4)$; and $84.9 \%$ indicate that they change their communication style when interacting with different clients $(\underline{M}=2.89)$. In order to get a better picture of how the precise communication style variable (which seems to be the strongest predictor of income), income and these sales practice measures were interrelated, 
Pearson product moment correlation coefficients were calculated. Table 6 provides these correlations. As can be seen from the table, there is a strong correlation between a person's rating of him or herself in terms of sales performance and income $(r=.568)$. It is also interesting to note that there is a relationship between an individual's communication style in a sales situation being different from what it is on a general basis and an individual's changing his or her communication style with different clients $(r=.516)$.

The ability of the sales practice variable to predict income was examined by performing a stepwise regression on income. Two steps of regression were completed with an $R^{2}$ of $.383, \underline{F}(2,60)=18.66, p<.001$. Perception of self in terms of sales performance and number of weekly hours worked emerged as the two significant predictors of income. See Table 7 for the beta weights and significance levels. What appears to emerge from this latter analysis is that people who see themiselves as good sales performers tend to be effective salespeople.

As a further follow-up, a stepwise regression analysis was performed on the general sales practice variables using weekly income per hour as the dependent variable. One step of regression was completed with an $\mathrm{R}^{2}$ of $.147, \underline{F}(1,61)=10.51$, $p<.01$. Perception of self was the only variable associated with weekly income per hour worked.

In addition, in order to obtain a more detailed understanding of the relationship between the communication 
style measures and the weekly income per hour worked, a second stepwise regression analysis was performed on the communicator style variables using weekly income per hour as the predictor. The only two variables entered into the equation were Dominant and Animated. Two steps of regression were completed with an $\mathrm{R}^{2}=.139, \underline{E}(2,62)=4.99, p<.01$. These results are not surprising, however, since Dominant and Animated are from the same "set" of variables as is Precise (i.e. strong set).

Discussion

Precise appears to be an important indicator of sales success for these individuals as shown by the fact that (1) the only communicator style variable which was significantly related to the performance measures of income and company profit was precise, (2) the step-wise regression for the communicator style variables includes precise as a significant predictor of income, and (3) precise is also entered into one of the functions for the discriminant analysis. Norton (1978) defines precise as a communicator who tries to be strictly accurate when arguing, prefers well-defined arguments, and likes proof or documentation with arguing.

On the basis of these results, one can separate the eleven communicator style measures into two categories: (1) strong variables and (2) casual variables. The strong variables are animated, dramatic, dominant, contentious, and precise whereas the casual variables are friendly, attentive, open, and relaxed. Impression-leaving and communicator image would be 
considered neutral since they could conceivably fall into either category.

The cluster functions seem to be describing two distinct types of salespeople in terms of their communication style. As a result of the animated, dramatic, dominant, friendly and contentious communicator styles falling together, the first function seems to be describing an individual who is very outgoing. For the mostpart this type of individual displays communicator style variables which fall into the strong category, with the exception of friendly. The second cluster function describes an individual who demonstrates the impression-leaving, attentive, precise, open and relaxed communicator styles with the exception of precise, these variables fall into the casual category.

Again, the precise variable emerged as significant in the correlation, regression and cluster analyses. However, the Cluster analysis also shows that individuals who score high on the impression-leaving, attentive, open and relaxed measures are also scoring high on the precise communicator style measure. As noted earlier, precise falls into the "strong" variable category while impression-leaving, attentive, open and relaxed fall into the "casual" category. It seems that when precise is "blended" into a combination of variables that are casual; it may take on new meaning. In addition, the combination of casual variables may also take on new meaning. In other words, one may moderate the other. The reader should 
note that this appeared to be the case in the Notarantonio and Cohen (1988) study. In addition, Norton (1983), in his work on social magnetism, found that attentive, friendly, relaxed and open are all predictors of attraction. However, Norton cautions that these findings may be mediated by context, situation, and time. In relation to this, it would seem that the salesperson who possesses only those styles that Norton identifies as predictors of attraction, (attentive, open, relaxed and friendly), might not be perceived as very businesslike; but when precise is "blended" with these variables, as was the case with the cluster analysis, a communicator who is better suited to a business situation emerges.

Likewise, a second set of variables that seem to fall together in both the correlation and cluster analysis includes animated, dominant, dramatic, friendly and contentious. With the exception of friendly, these variables fall into the "strong" communicator style category. Again, blending the friendly variable into a set of "strong" styles may serve to moderate the set and vice-versa.

The Pearson Product Moment Correlations revealed that there was no correlation between any communicator style variables and sales practice variables.

The stepwise regression analysis on the sales practice variables did show that, successful sales performance (as indicated by income), seems to be, in part associated with: 
one's perception of his or herself as above average terms of sales performance, and (2) number of hours worked. What this seems to be saying is that, in part, motivation and effort are determinants of sales success. The reader should again note that the second regression analysis which used weekly income per hour as the dependent variable showed that number of hours worked was covarying with income.

\section{STUDY 2 - METHOD}

The analyses from the field study indicate that the precise communicator style variable is a very important contributor to sales success. By manipulating this variable in a controlled setting, one can empirically test whether precision affects sales effectiveness. Along with precise, the researcher chose to manipulate the friendly communicator style variable. The friendly subconstruct was chosen for a number of reasons: (1) Norton (1978) states that the friendly style dimension is a solid predictor of attraction, leadership, and socialability;

all factors that seem necessary for sales effectiveness, The Pearson product moment correlation analysis from the field study shows that precise and friendly are not significantly correlated ( $r=.0127)$, and (3) it seems reasonable intuitively that a salesperson who is friendly would be perceived as more effective than one who is not, and so friendly was to be manipulated along with precise in order to examine independent observer perceptions of various combinations of these subconstructs. 
This study empirically tests whether or not the precise and friendly communicator styles were related to sales effectiveness. The Precise and Friendly styles were used from Norton's dimensions. Four combinations of communication style were generated by combining these subconstructs. The four unique combinations of style variables used to operationally define the types of communicator styles were: high Precise/high Friendly, low Precise/high Friendly, high Precise/low Friendly and low Precise/low Friendly. The effect of combining and manipulating different levels of these variables on perceptions of a sales interaction by independent observers was investigated. A number of studies of communicator style have taken this approach of utilizing independent observers in order to examine perceptions. Pace (1962) examined the relationship between oral communication and sales effectiveness. Objective observers rated two groups of salespeople who had been differentiated into an effective " high" group and a less effective "low" group. Bednar (1982) obtained independent evaluations of communicator style and performance for managers from two organizations. Graetz (1974) also used independent observers in a study of relationships between aspects of verbal behavior of supermarket store managers and their managerial effectiveness. It was hypothesized that the more precise a salesperson is, the more effective the individual will be in selling the product and the more positively s/he will be perceived by others. It 
was also hypothesized that the more friendly the salesperson, the more effective $s /$ he will be. These variables may also interact but no specific effects were predicted.

\section{Subjects}

Subjects consisted of undergraduate Business Administration students enrolled at Bryant college. One hundred twelve subjects participated in the study. A demographic analysis revealed that $50.9 \%$ of the respondents were male and $49.1 \%$ were female. Students ranged in age from 17 to 39 years with $60.3 \%$ of subjects being between 19 and 21 years of age. Freshmen accounted for $11.7 \%$, sophomores for $24.3 \%$, juniors for $35.1 \%$ and seniors for $28.8 \%$ of the sample. The percentage of respondents indicating that they have purchased at least one car on their own was 59.6\%. Forty-four percent of the subjects have held sales positions.

\section{Apparatus}

Four videotapes were produced by combining low and high levels of preciseness and friendliness. Each of the tapes depicted one of the four combinations of communicator style types. The scripts were developed in a way so that the "content" of the sales presentations were as similar as possible across conditions except to reflect the differences in communication style. Keeping in line with Norton's definitions, preciseness was manipulated by varying the degree of detail and accuracy which the salesperson provided to the customer. Friendliness was manipulated by varying the degree 
to which the salesperson expressed admiration for, encouraged, and acknowledged the contributions of the customer (see Appendix ( for scripts).

The hypothetical product being sold in all tapes was a new automobile. An automobile was chosen because, (1) like a home, it represents a major purchase, (2) New automobile salespeople can be categorized with real estate salespeople in terms of how they are perceived by the consuming public, and (3) the probability of students having had experience with the purchase of an automobile, or more specifically in dealing with an automobile salesperson, is higher than that of their having had experience with the purchase of a home or dealing with a real estate agent. The tape simulated an automobile showroom. The customer had just supposedly been shown a new automobile. The scenario in the videotape involved the salesperson and customer walking over to sit at a desk and discuss the auto that has just been seen. The interaction begins here and was varied depending upon the condition. The customer in the tape remained neutral and did not vary his style among conditions. It was the salesperson whose style was manipulated. Both actors were male and approximately twenty-one years of age. Both were average in height. Each tape was approximately three minutes in length.

Each of the four videotapes were pretested by showing them to small groups of subjects $(n=10)$. Respondents were then asked to complete a communicator style measure which included 
measures of preciseness and friendliness. These measures were seven-point scales of agreement with the value of 1 indicating strong agreement of possessing the trait. This was done in order to ensure that the communicator style being depicted on the tape was actually being perceived by the subjects.

A two-way analysis of variance (low-high Preciseness $x$ lowhigh Friendliness) was performed for each of these two measures. For the measure of preciseness, a significant main effect between the low Preciseness $(\underline{M}=4.75)$ and the high Preciseness $(\underline{M}=3.32)$ groups, $\underline{F}(1,38)=10.01, p<.01$ was found.

For the friendliness variable there were significant main effects between the low Friendly $(\underline{M}=4.95)$ and the high Friendly $(\underline{M}=2.67)$ groups, $\underline{F}(1,38)=23.29, p<.001$. These results indicate that the tapes were perceived as intended. Subjects perceived the salesperson in terms of preciseness and friendliness as manipulated.

\section{Procedure}

Subjects were randomly assigned to conditions. In addition, within each condition, time of day and day of week were randomized. Groups of no more than five or six subjects were run at a time.

subjects were asked to sign an informed consent form after which they were shown a videotape of the sales presentation (see Appendix D). After viewing the tape, subjects were asked to complete a questionnaire consisting of a series of 40 
Likert-type items. The questionnaire consisted of items containing communicator style measures, items measuring attraction to the communicator, perceptions of the ability of the communicator as a salesperson, respondents' judgments of the probability of purchasing from the communicator, perceived similarity of the sales activity involved in selling a home and that involved in selling an automobile as well as demographic information (see appendix D).

\section{Results}

In order to examine whether there were differences between the conditions and between males and females in terms of how the interaction in the tapes were being perceived, separate three-way ANOVA's were run with Preciseness, Friendliness and Sex for the communicator style variables as well as for selected questionnaire items. All measures ranged from 1 (strongly agree) to 7 (strongly disagree).

The precise and friendly measures were first examined to be certain that the communicator styles were again being perceived as manipulated. For the precise construct, there were significant main effects for the Precise condition as well as an interaction with friendliness. Subjects in the high Precise group saw the salesperson as more precise ( $\underline{M}=$ 3.59) than those in the low Precise group $(\underline{M}=4.66), \underline{F}(1,100)$ $=10.798, p<.01$. In terms of the interaction, subjects in the high Precise condition rated the salesperson as more precise in 
the low Friendly condition $(\underline{M}=3.00)$ than in the high Friendly condition $(\underline{M}=4.10), \underline{F}(1,100)=5.197, p<.05$. However, in the low Precise condition perceptions of Preciseness were not as differentiated across friendliness.

For the friendly measure, there were significant main effects for the Friendly condition as well as a significant precise $x$ friendly interaction. Subjects in the high Friendly condition saw the salesperson as more friendly $(\underline{M}=3.52)$ than those in the low Friendly condition $(\underline{M}=4.94), \underline{F}(1,100)=$ $27.597, p<.001$. The two-way precise $x$ friendly interaction shows that in the low precise condition there were much smaller differences in perceptions of friendliness between the low Friendly $(\underline{\underline{M}}=4.85)$ and the high Friendly $(\underline{M}=4.43)$

conditions. When viewing high Preciseness however, subjects in the high Friendly condition rated the salesperson as significantly more friendly $(\underline{M}=2.71)$ than those in the low Friendly condition $(\underline{M}=5.81), \underline{F}(1,100)=47.545, p<.001$. These results again indicate that the videotapes were being perceived as manipulated.

In order to examine which communicator style variables were related, Pearson product moment correlations were calculated and are shown in Table 8. As can be seen from the table, friendly, is positively related to open, attentive, communicator image and negatively related to dominant. The only other variable that precise is related to is impressionleaving. 
To further investigate how the groups were differing on their perceptions of the sales interaction the ANOVA's for all the communicator style variables as well as for other items relevant to the results of this study were examined. Table 9 provides significant findings for these ANOVA's. As one can see from the table, there were main effects for Preciseness with the precise, animated, dramatic, dominant and impressionleaving measures. Also, in addition to "friendly" main effects on the friendly variable, the only other variable that was significant was the open subconstruct.

There were some significant interactions as found in the ANOVAs performed on the questionnaire items. Table 10 shows the cell means for the measure of Dominance. This interaction shows that subjects in the low Friendly condition saw the salesperson as more dominant in the high Precise condition than in the low Precise condition. However, in the high Friendly condition there were much smaller differences in perceptions of Dominance from low Precise to high Precise $\underline{F}(1,108)=15.012$, $\mathrm{p}<.001$.

The cell means for the measure of "This salesperson monopolized the conversation in the Precise $x$ Friendly interaction are shown in Table 11. Subjects in the low Friendly condition perceived the salesperson as monopolizing the conversation more in the high Precise than in the low Precise condition. Differences in perceptions of monopolizing were not as clear between low Precise and high Precise in the 
high Friendly condition $\underline{F}(1,108)=5.730, p<.05$.

As shown in Table 12, respondents in the low Friendly condition rated the interaction between the salesperson and the customer as more strained in the high Precise condition than in the low Precise condition. In the high Friendly condition again, there were smaller differences $F(1,107)=$ $13.48, \mathrm{p}<.001$.

Table 13 shows that respondents in the low Friendly condition indicate that they would be less likely to do business with a salesperson in the high Precise condition than in the low Precise condition. In the high Friendly condition, however, differences in responses between low Precise and high Precise were not as clear $\underline{F}(1,107)=15.129, p<.01$.

Finally, Table 14 illustrates the interaction for the likelihood that respondents would have bought the product from the salesperson in the tape. Subjects in the low Friendly condition indicate that they would be less likely to have bought the product from the salesperson in the high Precise than in the low Precise condition. However, in the high Friendly condition there were very small differences in responses between the low Precise and the high Precise conditions $\underline{F}(1,108)=6.344, p<.05$.

All of these interactions show that subjects in the low Friendly condition saw the salesperson or the situation in a less positive way in the high Precise condition than in the low Precise condition whereas, perceptions of the measure did 
not change much from low Precise to high Precise in the high Friendly condition.

\section{Discussion}

The high precise communication style does not appear to be the most effective one for a sales situation, at least when viewed in a controlled situation. Respondents indicated that they would be less likely to do business with and less likely to purchase the product from the salesperson in the tape who demonstrated high Preciseness. Also, the interaction was seen as more strained and the salesperson was seen as monopolizing the conversation more when the high Precise communicator style was demonstrated. Perhaps customers may feel that they are being inundated with information overload when dealing with a salesperson who demonstrates the precise communication style in isolation.

As pointed out earlier, there were main effects for Preciseness with the animated, dramatic, dominant and impression-leaving measures. In all of these cases, subjects were viewing the salesperson as higher on the given subconstruct in the high Precise condition than in the low Precise condition. The Pearson product moment correlations also show that these variables are interrelated. These communicator style variables all fall into the "strong" category discussed in the previous study and seem indicative of what might be seen by independent observers of a sales interaction as an outgoing, and perhaps overpowering 
communicator. This combination of variables appears to be somewhat similar to the combination of "strong" variables that came together in the field study, with a major exception "friendly", a casual variable, was blended into the combination in the field study. As pointed out earlier, this can change perceptions dramatically. This was also illustrated by the twoway friendly $x$ precise interactions shown in Tables 10 through 14. These interactions seem to șggest that, although preciseness, when considered in isolation, seems to be viewed in a negative way, friendliness may moderate this perception. If a salesperson displays friendliness along with preciseness, perhaps customers will not feel as overwhelmed. Again, this point is demonstrated by the fact that in the tape, subjects were not viewing the high precise salesperson in a less positive way than the low precise salesperson when high preciseness was coupled with high friendliness as they were doing in the low Friendly condition.

The friendly subconstruct is positively related to openness, attentiveness and communicator image and negatively related to dominance. In addition, since attentiveness, openness and friendliness are all positively related to communicator image, which Norton (1978) identifies as the dependent variable in his domain, it seems that a salesperson displaying these styles would be viewed in a positive way. Norton (1983) found that a person who is perceived to be friendly, attentive and relaxed in his or her style of 
communication is seen as more attractive than a person who does not interact this way. This combination of "casual" styles is very close to that combination described in the field study.

Although in the field study, those salespeople who saw themselves as more precise reflected greater sales effectiveness, it appears that the automobile salesperson who was a precise communicator was not perceived in a positive way. one possible explanation for this could be that, although the buying processes for home and automobiles may be similar, the purchase of a home seems to be a more rational process whereas the purchase of an automobile may be more emotional in nature. It seems reasonable that a home buyer would be very concerned with obtaining the most accurate information and details about what is probably the major purchase of his or her lifetime. This need for such accuracy and detail may be unique to the purchase of a home. On the other hand, the buyer who is susceptible to emotional appeal in a sales interaction as may be the case with the automobile buyer, may be more receptive to a salesperson who displays the friendly, attentive, and open styles.

one must use caution, however, when interpreting these findings in terms of one isolated communicator style variable. In reality, a person would rarely demonstrate only one communication style. As point out a number of times in this study, different combinations of styles can change perceptions of sales effectiveness. In addition, Pace (1962) found that 
ratings of sales people on separate communication styles taken one at a time, failed to distinguish between the more effective and the less effective salespeople in his sample. He draws the conclusion that generalized communication skill should be emphasized more than isolated details of communication behavior.

In terms of this study, rather than to examine any one variable in isolation, it may be more meaningful to look at a given variable's contribution to different combinations of communication style and their differences in terms of actual or perceived sales performance.

\section{Future Research}

Since communication style in a marketing context remains a relatively new field of investigation, there are several directions in which future research can move:

A field study that investigates differences in communication style among salespeople of an organization other than real estate would allow the researcher to examine which variables hold up across context and situation as well as what new variables might emerge.

Examination of customer's perception of sales interactions in a field setting would be of interest. The williams and Spiro (1985) study used this approach. This kind of approach gets away from the problems associated with self-report measures and increases the external validity of lab results. Finally, as a possible extension of the present study, the 
researcher may want to manipulate combinations of several communicator style subconstructs in a controlled situation. For example combining friendly, attentive, relaxed and precise and comparing perceptions of a communicator displaying this combination with perceptions of a communicator displaying the combination without precise might give a more detailed analysis for this phenomena.

In summary, research which uses communication style as a way of understanding sales effectiveness is very scanty. It appears to be an approach which provides new insights and there are many directions in which it can move. 
Table 1

Means and standard Deviations for the Questionnaire Items

\begin{tabular}{|c|c|c|}
\hline Variable & $\underline{M}$ & $\underline{\mathrm{SD}}$ \\
\hline Copro & 101.40 & 66.55 \\
\hline Income & 3317.74 & 2208.69 \\
\hline Dominant & 3.25 & 1.79 \\
\hline Friendly & 1.55 & .71 \\
\hline Attentive & 2.03 & 1.14 \\
\hline Relaxed & 2.60 & 1.53 \\
\hline Contentious & 4.51 & 1.99 \\
\hline Dramatic & 3.45 & 1.86 \\
\hline Animated & 2.70 & 1.57 \\
\hline Open & 3.42 & 1.88 \\
\hline Impression-leaving & 2.58 & 1.31 \\
\hline Precise & 2.88 & 1.44 \\
\hline Communicator image & 2.03 & 1.34 \\
\hline Persuasive Communicator & 2.35 & 1.02 \\
\hline CS can be manipulated & 4.49 & 2.23 \\
\hline cs is important for a sale & 1.64 & 1.33 \\
\hline Rate own sales performance & 3.12 & 1.50 \\
\hline CS different for client & 4.00 & 1.84 \\
\hline Change CS for diff clients & 2.89 & 1.49 \\
\hline Training included CS & 3.37 & 1.62 \\
\hline Avg. time for a sale* & 1.44 & .60 \\
\hline Avg. no. hours work/wk* & 4.94 & 1.35 \\
\hline Length of time w/ co.* & 5.34 & 1.47 \\
\hline Units sold in past yr.* & 4.13 & 1.92 \\
\hline sDscore & 20.51 & 4.68 \\
\hline
\end{tabular}

Note: All items are seven-point scales of aggreement with 1 indicating strong agreement of possessing the trait with the exception of those items indicated by * ). 


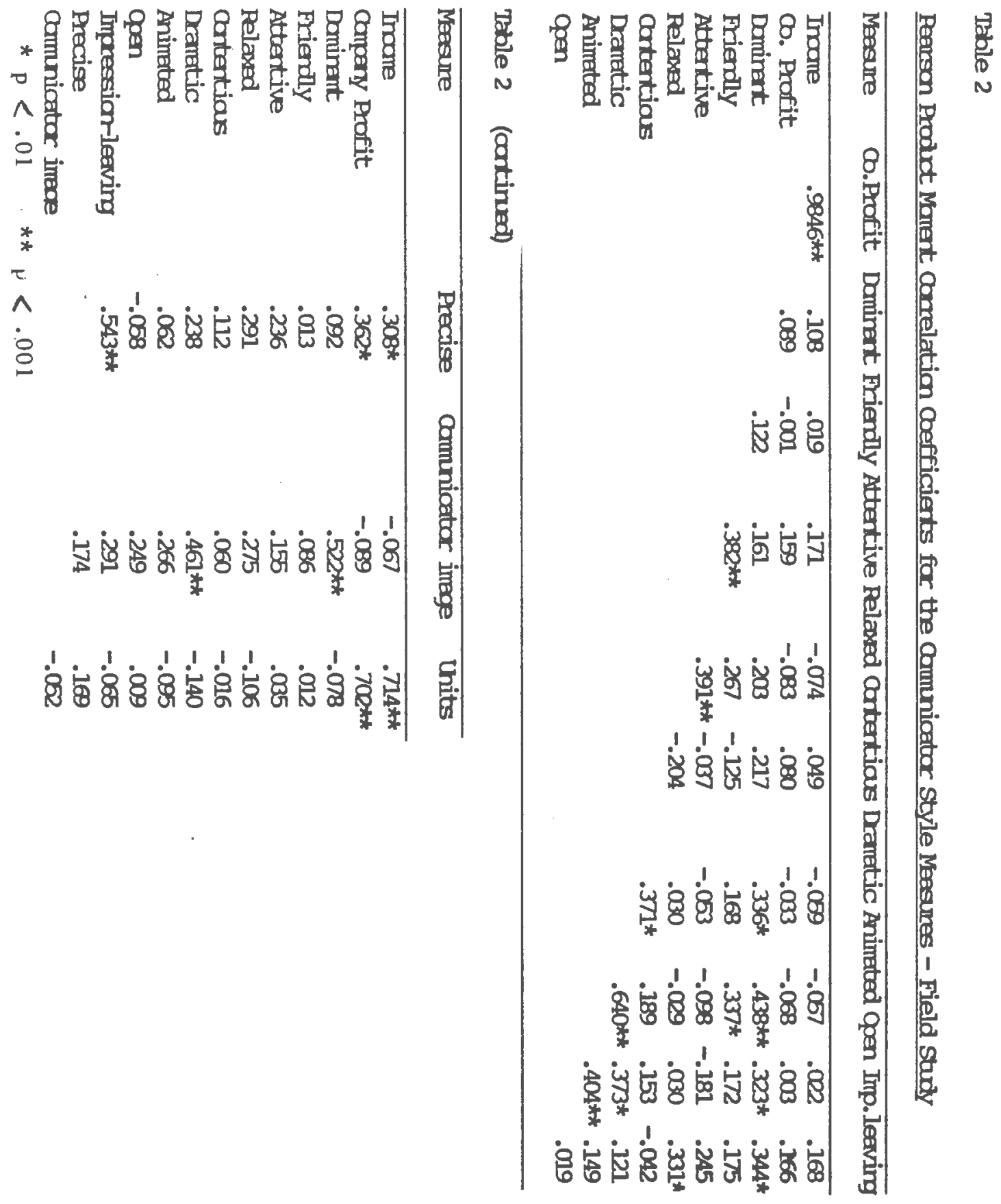


Table 3

Beta Coefficients for stepwise Regression on Income for the Communicator Style variables

\begin{tabular}{|c|c|c|c|}
\hline Variable & $\bar{B}$ & $t$ & $p$ \\
\hline Dominant & .068 & .581 & $>.05$ \\
\hline Friendly & .032 & .277 & $>.05$ \\
\hline Attentive & .117 & .998 & $>.05$ \\
\hline Relaxed & -.169 & -.445 & $>.05$ \\
\hline Contentious & .005 & .043 & $>.05$ \\
\hline Dramatic & -.127 & -1.077 & $>.05$ \\
\hline Animated & -.082 & -.707 & $>.05$ \\
\hline Open & .035 & .306 & $>.05$ \\
\hline Impression-leaving & .016 & .119 & $>.05$ \\
\hline Precise & 511.813 & 2.842 & $<.01$ \\
\hline
\end{tabular}


Table 4

Univariate F-Ratios and Standardized Discriminant Coefficients. for the Three cluster solution for the CSM's

\begin{tabular}{|c|c|c|c|c|}
\hline \multirow[b]{2}{*}{ Subconstruct } & \multirow[b]{2}{*}{$\underline{F}$} & \multicolumn{3}{|c|}{ Standardized Coefficient } \\
\hline & & $\underline{\mathbf{p}}$ & function 1 & function 2 \\
\hline Dominant & 15.16 & $p<.001$ & .328 & .124 \\
\hline Friendly & 3.76 & $p<.05$ & (not & entered) \\
\hline Attentive & 14.03 & $\mathrm{p}<.001$ & .441 & .538 \\
\hline Relaxed & 2.43 & $\mathrm{p}>.05$ & -.276 & -.086 \\
\hline Contentious & 1.51 & $p>.05$ & (not & entered) \\
\hline Dramatic & 26.08 & $p<.001$ & .243 & -.036 \\
\hline Animated & 81.79 & $\mathrm{p}<.001$ & .788 & -.400 \\
\hline Open & 10.01 & $p<.001$ & .040 & -.380 \\
\hline Impression-leaving & 32.84 & $\mathrm{p}<.001$ & .114 & .768 \\
\hline Precise & 17.09 & $\mathrm{p}<.001$ & .428 & .273 \\
\hline
\end{tabular}

Note: All F-ratios have 2 and 67 degrees of freedom. 
Table 5

Means and Standard Deviations for the CSM Subconstructs for the Cluster Groupings

\begin{tabular}{|c|c|c|c|c|c|c|}
\hline \multirow[b]{2}{*}{ Subconstruct } & \multicolumn{2}{|c|}{$\begin{array}{c}\text { Cluster } 1 \\
(n=43)\end{array}$} & \multicolumn{2}{|c|}{$\begin{array}{r}\text { Cluster } 2 \\
(\mathrm{n}=16)\end{array}$} & $\begin{array}{r}\text { Cluster } 3 \\
(n=11)\end{array}$ & \multirow[b]{2}{*}{$\underline{S D}$} \\
\hline & $\underline{\underline{M}}$ & $\underline{\underline{S D}}$ & $\underline{\underline{M}}$ & $\underline{\mathrm{SD}}$ & $\underline{M}$ & \\
\hline Dominant & 2.44 & 1.40 & 4.19 & 1.76 & 4.82 & 1.53 \\
\hline Friendly & 1.36 & .54 & 1.69 & .70 & 2.00 & .10 \\
\hline Attentive & 1.72 & .88 & 3.19 & 1.22 & 1.73 & .90 \\
\hline Relaxed & 2.35 & 1.46 & 3.25 & 1.46 & 2.36 & 1.36 \\
\hline Contentious & 4.26 & 2.04 & 4.69 & 1.78 & 5.36 & 1.63 \\
\hline Dramatic & 2.81 & 1.58 & 3.56 & 1.31 & 6.27 & .65 \\
\hline Animated & 2.00 & .85 & 2.63 & .96 & 5.73 & .79 \\
\hline Open & 3.16 & 1.70 & 2.63 & 1.15 & 5.36 & 2.01 \\
\hline Impression-lvg & 1.98 & .86 & 4.19 & .17 & 2.55 & .82 \\
\hline Precise & 2.30 & .96 & 4.31 & .58 & 3.09 & 1.30 . \\
\hline
\end{tabular}

Note: All scales range from 1(strong agreement) to 7 (strong disagreement). 


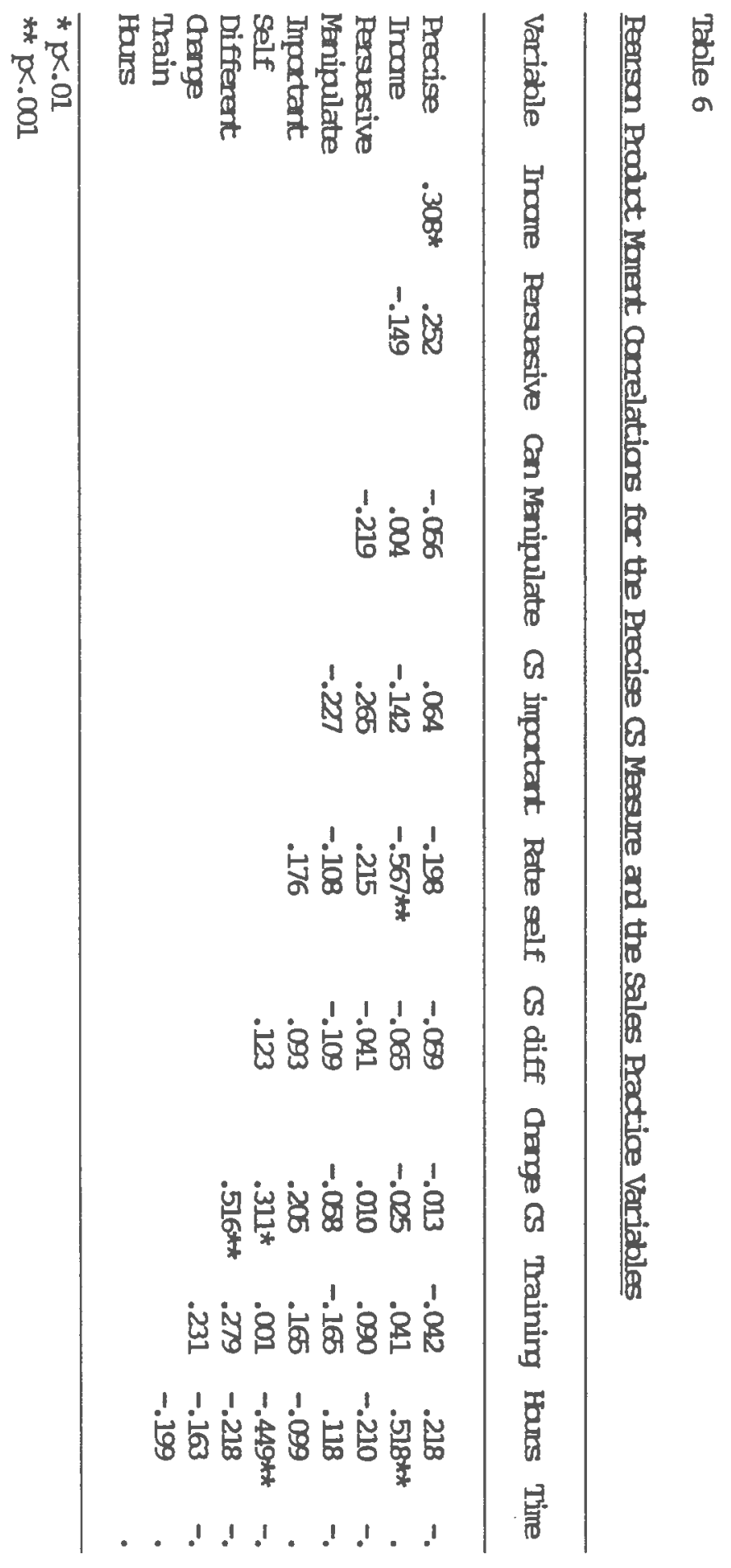


Table 7

Beta Coefficients for Stepwise Regression on Income for Sales practice Variables

\begin{tabular}{lccc}
\hline Variable & B & $t$ & $p$ \\
\hline Persuasive Communicator & -.065 & -.629 & $>.05$ \\
Can be manipulated & -.059 & -.568 & $>.05$ \\
Comm.Style impt.for sale & -.034 & -.331 & $>.05$ \\
Performance self-rating & -.416 & -3.7 & $<.001$ \\
Comm.Style diff.w/Client & .077 & .740 & $>.05$ \\
Change C.S. w/ diff.clients.195 & 1.892 & .05 \\
Avg. wkly hours worked & .313 & 2.803 & $<.01$ \\
\hline
\end{tabular}




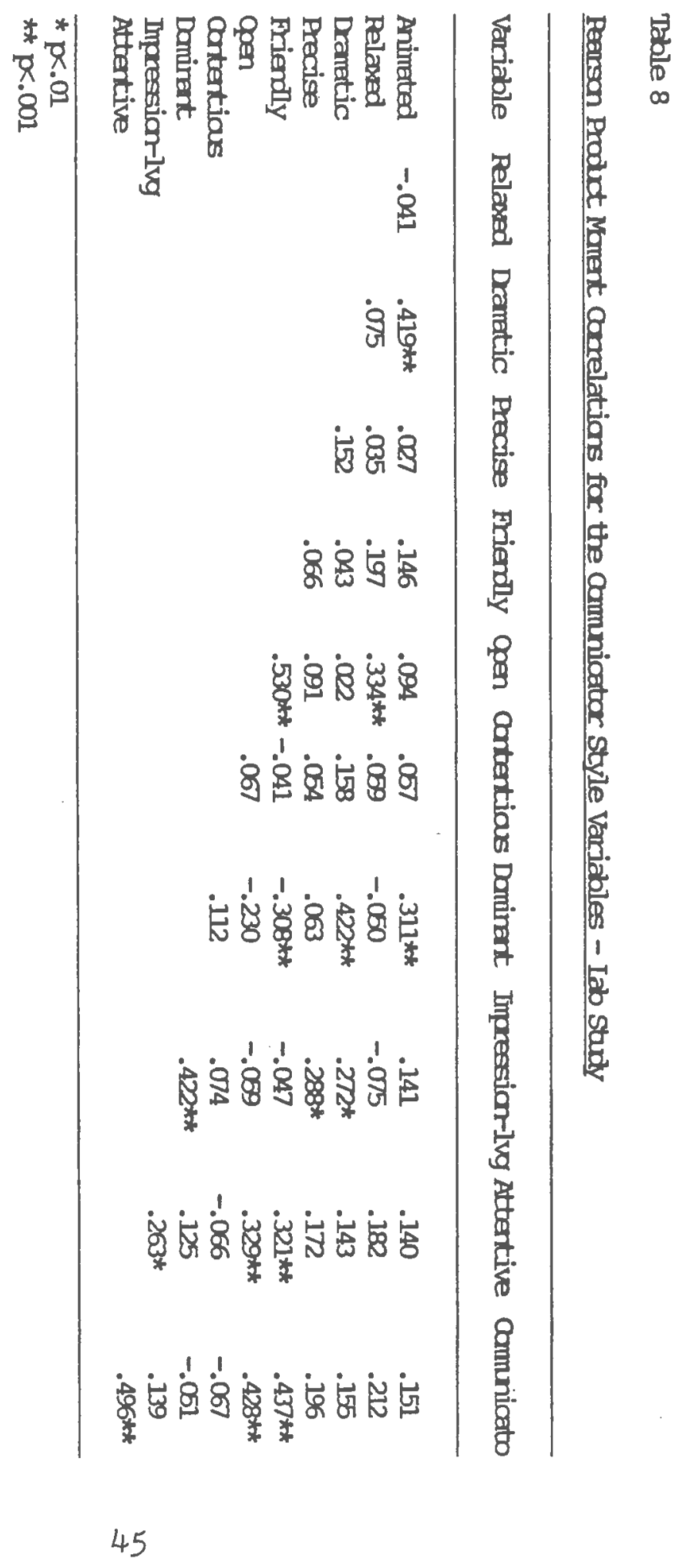


Tatie 9

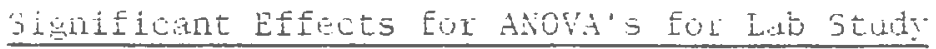

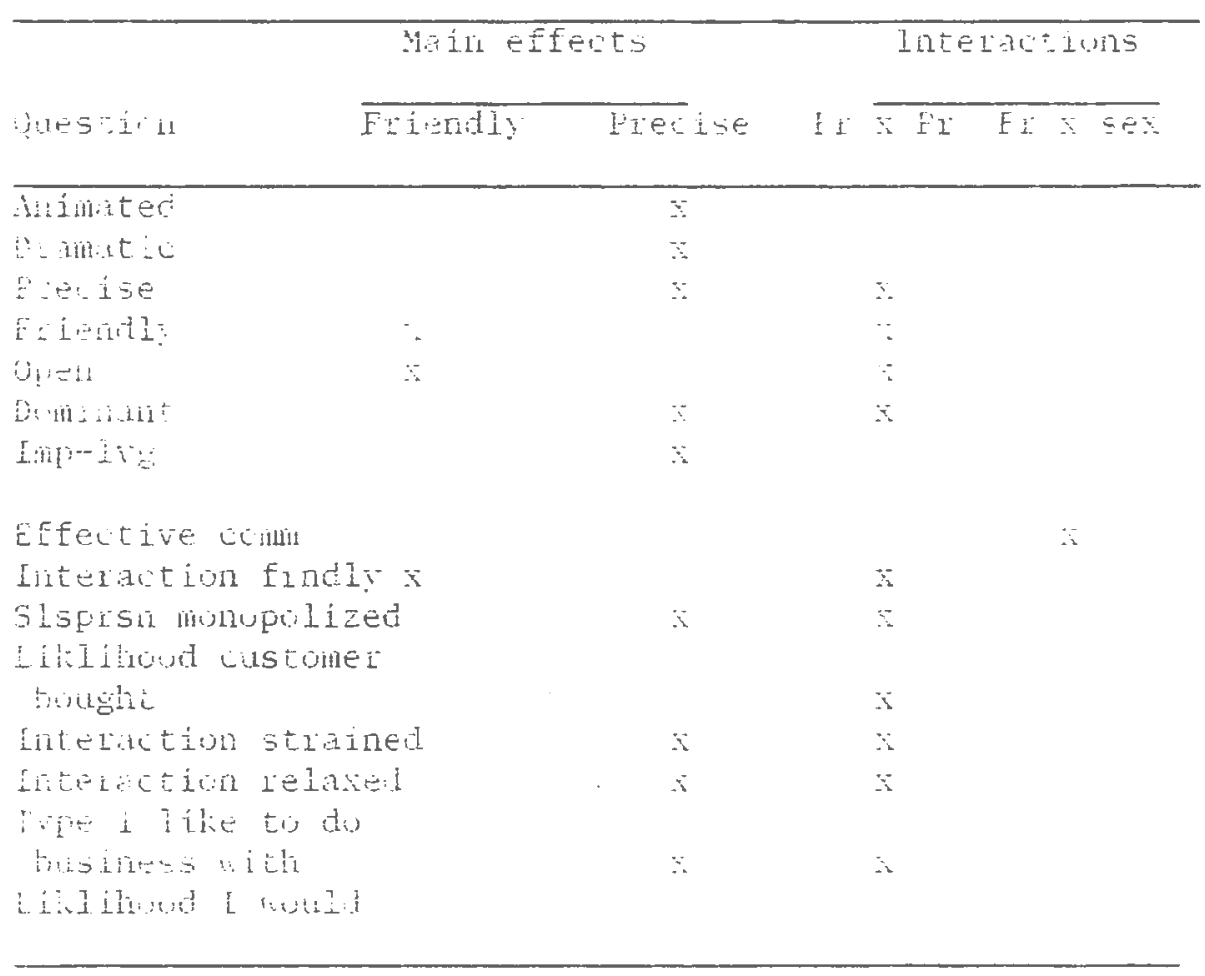


Table 10

Cell Means for the Measure of Dominance in the Precise $x$ Friendly interaction

\begin{tabular}{lcc}
\hline & \multicolumn{2}{c}{ Precise } \\
\cline { 2 - 3 } Friendly & low & high \\
\hline low & 3.41 & 1.59 \\
high & 2.04 & 2.16 \\
\hline
\end{tabular}


Table 11

Cell Means for the Measure of "This Salesperson Monopolized the conversation"in the Precise $x$ Friendly Interaction

Precise

Friendly

low

high

low

3.78

1.85

high

2.96

2.59 
Table 12

Cell Means for the Measure of "The Interaction was strained" in the Precise $x$ Friendly Interaction

\begin{tabular}{lcc}
\hline & \multicolumn{2}{c}{ Precise } \\
\cline { 2 - 3 } Friendly & low & high \\
\hline low & 3.62 & 2.15 \\
high & 2.65 & 3.06 \\
\hline
\end{tabular}


Table 13

Cell Means for the Measure of "The Salesperson

in the Tape is the Type I Like to do Business With"

in the Precise $x$ Friendly Interation

Precise

Friendly

low

high

low

5.35

6.78

high

6.39

6.34 
Table 14

Cell Means for the Measure of "The Liklihood that I would have Bought this Product from This Salesperson in the Precise $x$ Friendly Interaction.

\begin{tabular}{lcc}
\hline \multirow{2}{*}{ Friendly } & \multicolumn{2}{c}{ Precise } \\
\cline { 2 - 3 } & low & high \\
\hline low & 5.22 & 6.63 \\
high & 5.91 & 5.97 \\
\hline
\end{tabular}


Bass, B.M. (1960). Leadership, Psychology, and organizational Behavior. New York: Harper Bros.

Bass, B.M. (1967). Social behavior and the orientation inventory: A review. Psychological Bulletin, 68, 260-92.

Bednar, D.A. (1982). Relationships between communicator style and managerial performance in complex organizations: a field study. Journal of Business Communicantion, 19, 51-75.

Capon, N., Holbrook, M.B., \& Hulbert, J.M. (1977). Selling process and buyer behavior: Theoretical implications of recent research. In A.G. Woodside, J.N. Sheth \& P.D. Bennett (eds), Consumer and Industrial Buying Behavior. New York: Elsevier North Holland, Inc.

Churchill, G., Ford, N., \& Walker, 0. (1985). Sales Force Management. Homewood, IL.: Richard D. Irwin, Inc.

Churchill, G., Ford, N., Hartley, S. \& Walker, O. (1985). The determinants of salesperson performance: A metaanalysis. Journal of Marketing Research, 22, 103-18.

Crowne, D.P. Marlowe, D. (1960). A new scale of social desirability independent of psychopathology. Journal of Consulting Psychology, 24(4), 349-54.

Emery, D., Norton, R., \& Plain, H. (1980). Relaxed as a style ofcommunicating. Paper presented at the annual meeting of theInternation Communication Association, Acapulco, Mexico.

Friedman, M., \& Churchill, G.A., (1987). Using consumer perspectives and a contingency approach to improve health care delivery. Journal of consumer Research, 13, 492-510.

Graetz, H.G. (1974). Verbal Behavior and Managerial Effectiveness of Supermarket Store Managers. Unpublished D.B.A. Dissertation, Harvard University, Cambridge, Ma.

Norton, R. (1977). Teacher effectiveness as a function of communicator style. In B.D. Ruben (ed.), Communication Yearbook I. New Brunswick: Transaction Books.

Norton, R. (1978). Foundation of a communicator style construct. Human Communication Research,4 99-112. 
Norton, R. (1983). Communicator style: Theory, application and measures. Beverly Hills, CA: Sage Publications.

Norton, R., Baker, N., Bednar, D., Sayler, R., \& McGough, T. (1978). Impressions of interpersonal dramatic style. Paper presented at the annual meeting of the Speech Communication Association, Minneapolis, Mi.

Norton, R. \& Bednar, D.A., (1979). Ideal communicator style for the interviewee. Paper presented at the annual meeting of the International Communication Association, Philadelphia, Pa.

Norton, R., \& Miller, L. (1975). Dyadic perception of communication style. Communication Research, $\underline{2}$ 50-67.

Norton, R., \& Montgomery, B. (1979). An integration of style, content, and target in defining and measuring openness. Paper presented at the annual meeting of the International Communication Association, Philadelphia, Pa.

Norton, R., \& Nussbaum, J. (1980). Dramatic behaviors of the effective teacher. In Nimmo, D. (ed.) Communication Yearbook. 4 New Brunswick: Transaction Books.

Norton, R., \& Pettegrew, L.S. (1977). Communicator style as an effect determinant of attraction. Communication Research, 4, 257-82.

Norton, R., \& Robinson, D. Communicator style in career decisions. Paper presented at the annual meeting of the Speech Communication Association. New York.

Norton, R., Syphner, H., Clarke, C., \& Brady. (1977) . Dimensions of a dramatic communicator style. Paper presented at the annual meeting of the speech Communication Association, Washington, DC.

Notarantonio, E.M. \& Cohen, J.L. (1988). The effects of open and dominant communication styles on perceptions of the sales interaction. Journal of Personal selling and Sales Management. Under editorial review.

Pace, W.R. (1962). Oral communication and sales effectiveness. Journal of Applied Psychology, 44, 487-8. 
Sheth, J.M. (1976). Buyer-seller interaction: A conceptual framework. Proceedings of the Association for Consumer Research. Cincinnati, OH: Association for Consumer Research, 382-6.

Staley, C.C., \& Cohen, J.L. (1988). Communicator style and social style: similarities and differences between the sexes. Communication ouarterly. 36, 192-202.

Szymanski, David M. (1988). Determinants of selling effectiveness: The importance of declarative knowledge to the personal selling concept. Journal of Marketing, 52, 64-77.

Ward, J. H. (1963). Hierarchical grouping to optimize an objective function. Journal of American statistical Association, 58, 236-244.

Weitz, Barton A. (1981). Effectiveness in sales interactions: a contingency framework. Journal of Marketing, 45, 85103.

Weitz, B., Sujan, H., \& Sujan, M. (1986). Knowledge, motivation, and adaptive behavior: A framework for improving selling effectiveness. Journal of Marketing, 50, 174-191.

Weitz, B.A., Wright, P. (1978). The salesperson as a marketing strategist: The relationship between field sales performance and insights about one's customers. MSI Working Paper No. 78-120, Marketing Science Institute.

williams, K.C. \& Spiro, R.L. (1985). Communication style in the salesperson-customer dyad. Journal of Marketing Research. 22.434-42. 


\section{APPENDIX A}

COMAUICATOR STYLE DESCRIPTIONS 


\section{COMMUNICATOR STYLE DESCRIPTIONS}

Dominant

Tends to come on strong in most situations

Generally speaks very frequently

Tries to take charge of things when with people

Friendly

Readily expresses admiration for others

Habitually acknowledges verbally other's contributions

Tends to be encouraging to people

Attentive

Likes to listen very carefully to people

Can always repeat back to a person exactly what was meant

Deliberately reacts in such a way that people know $\mathrm{s} / \mathrm{he}$ is

listening

Relaxed

Doesn't have nervous mannerisms in speech

Under pressure comes across as a relaxed speaker

Rhythm or flow of speech not affected by nervousness

Contentious

When disagreeing with someone is very quick to challange

them

Won't drop an arguement that is not resolved

Dramatic

Regularly tells jokes, anecdotes, and stories

Physically and vocally acts out what s/he wants to say

Verbally exaggerates to emphasize a point

Animated

Constantly gestures while communicating

Actively uses a lot of facial expressions

Is very expressive nonverbally

Open

openly expresses feelings and emotions

Readily reveals personal things about self

Usually tells people alot about him/herself

Impression-leaving

What is said usually leaves an impression on others

Leaves people with an impression which they remember

The way something is said leaves and impression

Precise

Insists that other people document what they are saying

Likes to be strictly accurate when communicating

Insists upon very precise definitions 
APPENDIX B

EIELD STUDY QUESTIONNAIRE 
The inveat!gators of this etudy are attempting to exanine "artablec that ire assuclated with oales performance. In order :o to this your suparvisor has acresd, Wlth your permission, to provile the imuscigators with informatton bout your perforsance. Ince this information ids been obtained it will be

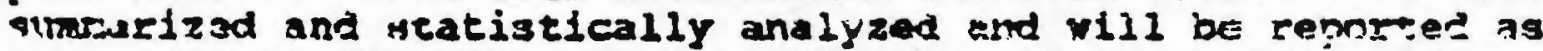
3461. IN NO WAX WILL YOO BE IOBHIIPISD IN THE SIUDY. If YOU tgei te to partzipipazo please aigb the rorm.

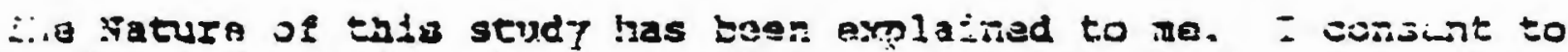
isving information about my sales performance disclcisid to tie iivestigators. In doing so I undarstand that the iarornation wil be sumarized, statisticolly analyzed and then destzoyet.

NANE (please print)

STGNATURE

s:-1:20-3 


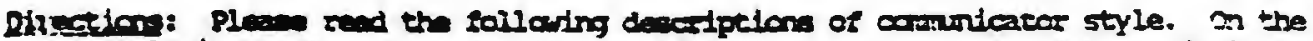
sole tollowing ench apoule deacription indicate the degres to which yive toel that

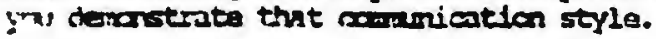

3. Detipont:

In mot socinl sitantion I tend to 00 on strang.

in wat socinl stantion I gonerally epank very inequently.

I try to take charge of things unan I an with pecple.

I a dodnerte in cocial tibuatere.

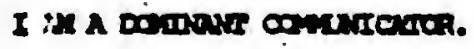

\begin{tabular}{|c|c|c|c|c|c|c|}
\hline & $\begin{array}{l}\text { cocisers } \\
\text { Meras }\end{array}$ & $\begin{array}{l}\text { swretx } \\
\text { iavex }\end{array}$ & $\begin{array}{l}\sqrt{\sin 20} \\
\operatorname{sen} 1\end{array}$ & $\begin{array}{l}\text { stretrux } \\
\text { Drsacieds }\end{array}$ & $\begin{array}{l}\overline{x D 0} \\
\text { DIS }\end{array}$ & \\
\hline
\end{tabular}

2. Pedenthy:

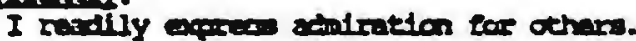

To be triendiy, I habitually adtowledge verbally other's contributions.

whenever I cominicate, I tend to be very encourruging to peoplc.

I a. always an extremaly eriendly comicator.

I AM A Fresioty conitionor.

\begin{tabular}{|c|c|c|c|c|c|c|}
\hline 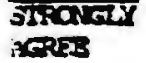 & inge & डाI & 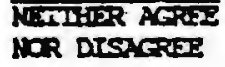 & $\begin{array}{l}\text { SLI } \\
\text { DUS }\end{array}$ & & \\
\hline
\end{tabular}

3. attentiv:

I mally like to listen very carasully to people.

I con always repsat beck to a person exacty whit was mant.



I an an extremely attentive cominieator.

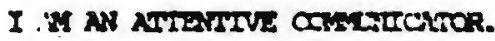

\begin{tabular}{|c|c|c|c|c|c|}
\hline 70 & 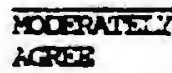 & $\begin{array}{l}\text { SLITRT } \\
\text { ACRES }\end{array}$ & 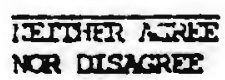 & & $\begin{array}{l}\text { MOD } \\
0123\end{array}$ \\
\hline
\end{tabular}

4. Belamed:

I do not hive nusvas manneriems in my spects.

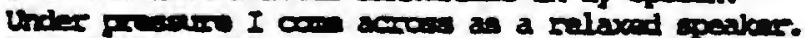

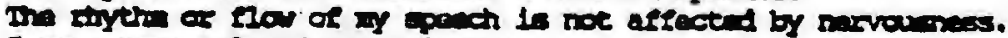

I a ver relased convingtor.

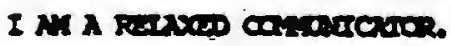

\begin{tabular}{|c|c|c|c|c|c|}
\hline 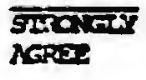 & 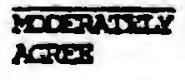 & 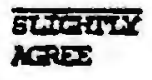 & 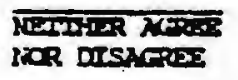 & 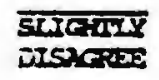 &  \\
\hline
\end{tabular}

5. Oxtentian:

When I dileagree with courbody I am very guidt to challenge then.

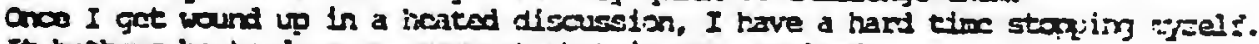

It bothers be to tirg an azqument that is not mesolved.

I an very argunantativa.

I MI A contrintous camanontor.

\begin{tabular}{|c|c|c|c|c|c|c|}
\hline 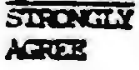 & 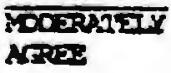 & $\begin{array}{l}\text { Stretum } \\
\text { ACES }\end{array}$ & $\begin{array}{l}\text { MBIMHDR ACEDSE } \\
\text { MOR DLSAGREE }\end{array}$ & $\begin{array}{l}\text { SITGHFY } \\
\text { OISACRES }\end{array}$ & $\begin{array}{l}\text { MOTRATDY } \\
\text { DISARAES }\end{array}$ & $\begin{array}{l}\text { SLEA:IIt } \\
\text { CLSACTS? }\end{array}$ \\
\hline
\end{tabular}


a Donter

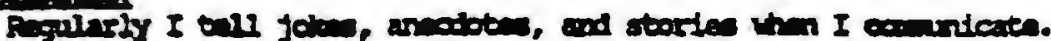

orted I popially and veally at at ibte I wint to couniate.

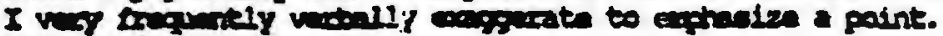

I cones a lot.

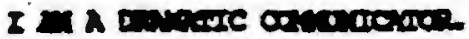

\begin{tabular}{|c|c|c|c|c|c|c|}
\hline SW0T & 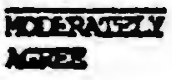 & $\begin{array}{l}\text { बIRAT } \\
\text { AFE }\end{array}$ & 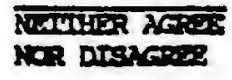 & $\begin{array}{l}\text { STratiu } \\
\text { DTsucis }\end{array}$ & 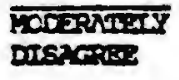 & $\begin{array}{l}\text { STrathy } \\
\text { DTstarex }\end{array}$ \\
\hline
\end{tabular}

7. 80dmotis

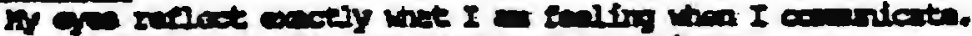

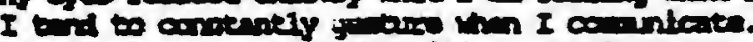

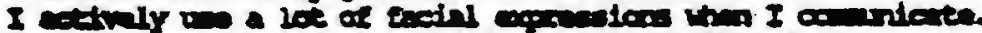

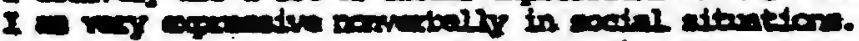

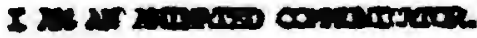



e. $\ln 2$

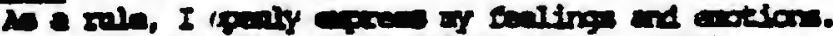

I redily rovel pesconl thing abate dyenle.

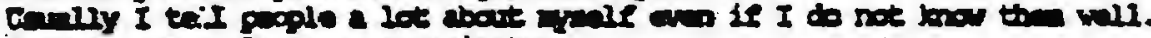

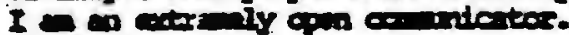

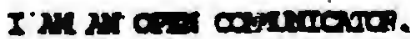

\begin{tabular}{|c|c|c|c|c|c|c|}
\hline 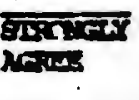 & 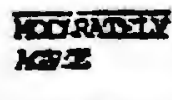 & 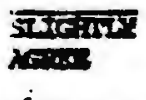 & 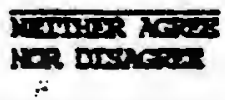 & 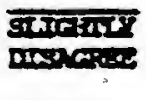 & 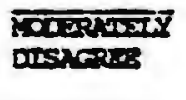 & $\begin{array}{l}\text { SIFATEYY } \\
\text { Drsagras }\end{array}$ \\
\hline
\end{tabular}

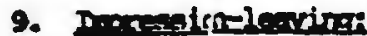





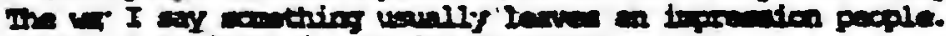

I leve a definite ingresesion on people.

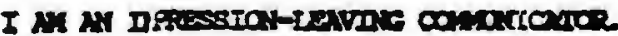

\begin{tabular}{|c|c|c|c|c|}
\hline 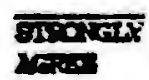 & 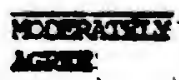 & बisctats & 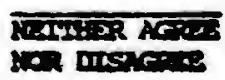 & 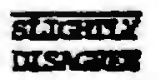 \\
\hline
\end{tabular}

10. Bexprian



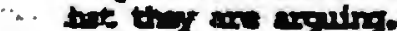

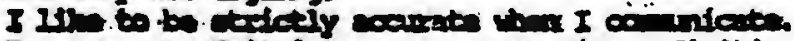

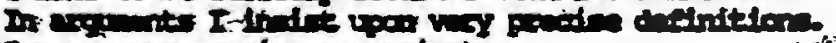

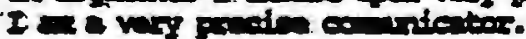

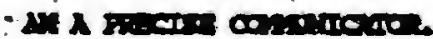

\begin{tabular}{|c|c|c|c|c|c|}
\hline 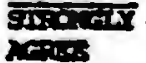 & $x_{20}^{\infty}$ & 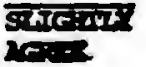 & 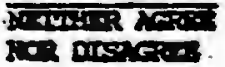 & 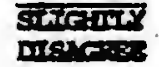 & $\begin{array}{l}\text { Docringent } \\
\text { Dusactes }\end{array}$ \\
\hline
\end{tabular}

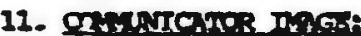

I an a very good comanicator.

I always find it very axy to commicate on a on-to-are basis with strengers.

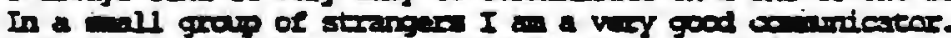

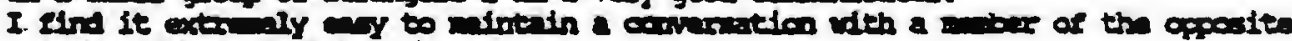
genc the I bove fore at.

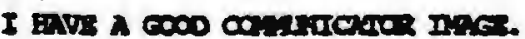

\begin{tabular}{|c|c|c|c|c|c|}
\hline $\begin{array}{l}\text { BDEThLY } \\
\text { Deves }\end{array}$ & 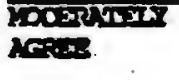 & 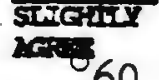 & 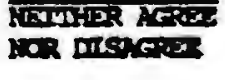 & $\begin{array}{l}\text { Sthetivy } \\
\text { orsictes }\end{array}$ & 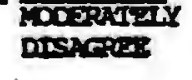 \\
\hline
\end{tabular}


P:S II

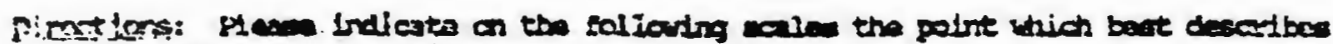
yoursiti andor your moctlana.

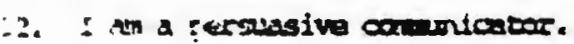

\begin{tabular}{|c|c|c|c|c|c|}
\hline Ezy & 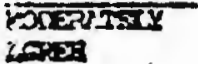 & Sure & 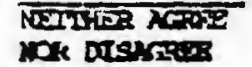 & 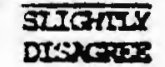 & $\begin{array}{l}\overline{x \times 2} \\
\text { ars }\end{array}$ \\
\hline
\end{tabular}

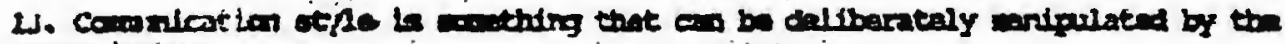
axconinicator.



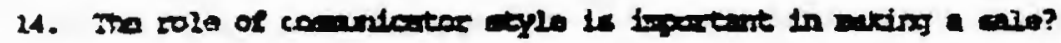



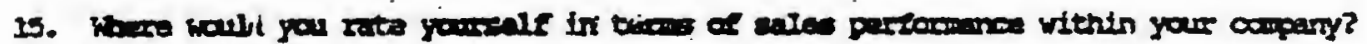

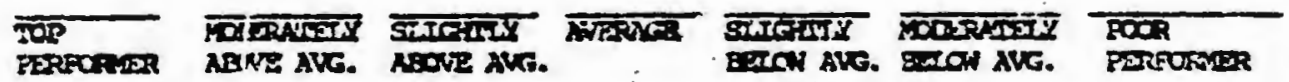

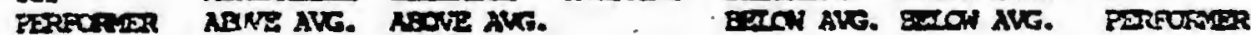

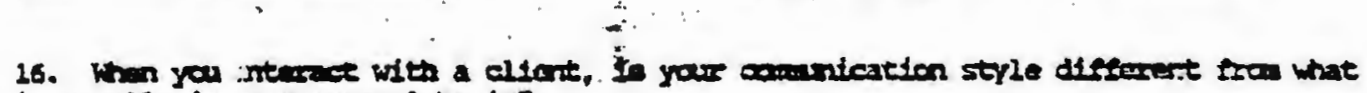
It unisliy is. sis a garnal basis?

त्मnYS

17. Do you ange your comaniation style iten lteracting with different cliente?



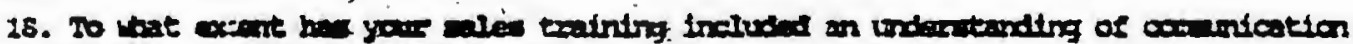

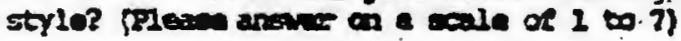

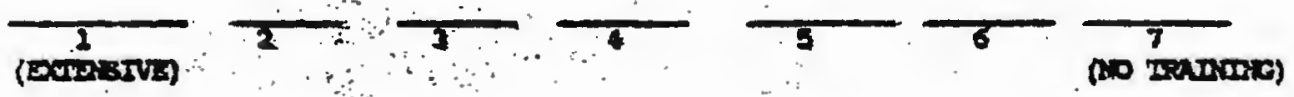

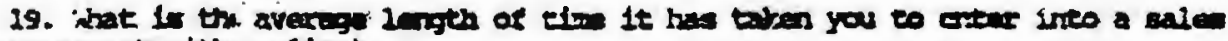
agremant with s cllont.

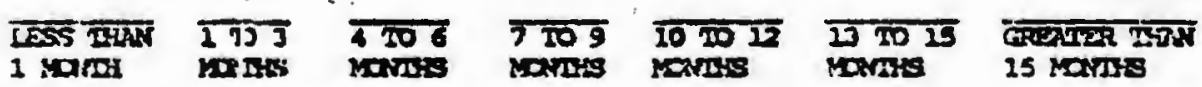


20. Do you work full-tiwe is part-time?

full-cine

parc-cine

21. What is the average nuber of hours per week that you work?

Less than 10 $\overline{\overline{10-13}} \overline{16-20} \overline{21-30} \overline{31-40} \overline{41-50} \overline{\text { sore than } 50}$
hours
hours bours hours bours hours hours

22. How long have you been working for your presenc conpany"

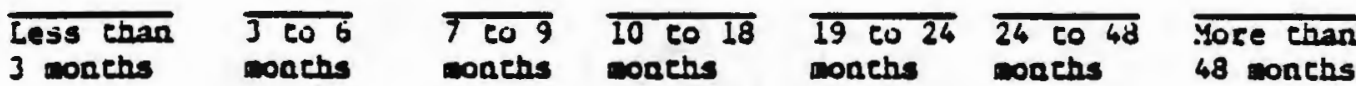

23. Bow unay units would you escinace that you bave sold within the pasc year?

$\begin{aligned} & \text { OEO } 2 \\ & \text { unies }\end{aligned}$ units
units
$\begin{aligned} & \text { unies } \\ & \text { units }\end{aligned}$

24. What is the geographical terricory that you are respoasible for? (please describe)

YOU WILI NOW BE ASKED SOME QUESTIONS ABOUT YOUR PERSONAL REACTIONS IN GENERAL. PLEASE BE GONEST ABOUT YOUR RESPONSES. TURN IHE PAGE AND DECIDE WHETHER EACE STATEMENT IS TRUE OR PALSE AS IT PERTAIXS TO YOU. 


\section{Percoñal Reaction Imentory}

Lleted below are a number of statasents concernting attftudes and tratts.

Read eich 1tem and decide whether the statement is true or false as it pertains to jou personelly and circle the corresponding leterer at the right.

1. Before voting I thoroughly investigate the qunlifications of all $T$ T the cand1dates.

2. I never hest tate to go out of my way to help someone in trouble. ' I F

3. It 1s sometimes bard for me to go on with wy work If I am not $T$ F encouraged.

4. I have paver Inteniely dsiliked axyoue.

5. On occaition I hrw had doubts sbout ay ablifty to succeed in I1fe. I

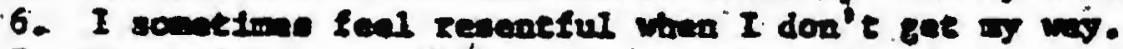

7. 'I a alwe cerefut sbout is maner of drese.

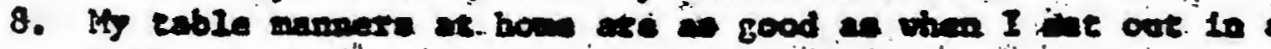
restanrane.

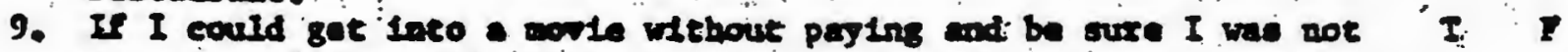
ween I nould probebiy do $1 t$.

10. On a few occastons, I have given up dolng sonething becarre I I I thought too little of wy abllity.

11. I like to goselp at times.

12." There have been times when I felt Ifke raballing againat people I in authortty cren though I knew they ware right.

13. No meter who I'm talletsi to, I'D clways a good.11stener.

14. I can renomber "pleytns atci" to get out of something.

15. There here been accaslons then I took adventage of ucomene.

16. I'm elway stlling to adutt it when I make a misenke.

17. I always try to practlce whet I preseh.

18. I don'e find it parteularly difficult to get along with loud mouthed, obnoxdoos people.

19. I sometines try to get even rather than forgive and forget.

20. When I don't koon someth1ng I don't at all mind admitelng it.

21. I a alveye courteou,, even to people who are disagreeable.

22. At times I heve really Ineisted on boving tbings uy own way.

23. There have been occasions when I felt like smashing things.

24. I would never think of letting sompone else be punished for mitrongdologa.

25. I never resent being asked to return a favor.

26. I hwe never been irked when people copizesead Idese very different from mosto

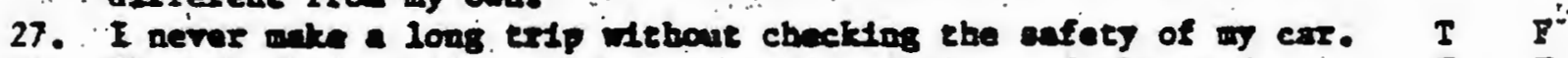

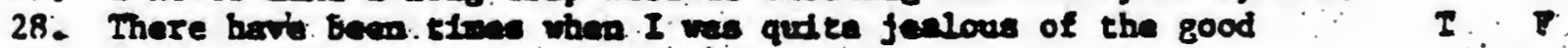
fortum of othere.

29. I heve afmose pever felt ib urge to tell someone off.

30. I ecmaefme tretteted by people who ask favors of we.

31. I heve never falt that I we puntahed wthout cause.


giot shat thay deserved.

33: I bave never deliberately and comithing that burt soweone's : I fentrage. 
APPENDIX C

SCRIPTS FOR SALES INTERACTION VIDEOTAPES

64 


\section{HIGH PRECISE/LOW FRIENDLY}

The precise communicator insists that other people document or present some kind of proof for what they are arguing. They like to be strictly accurate when they communicate. In arguments they insist upon very precise definitions.

The low friendly communicator does not readily express admiration for others. They do not habitually acknowledge verbally other's constributions. 
Scenario: Salesperson (S) and customer (C) enter the picture and sit across from each other at a desk. They have just left the showroom floor where the salesperson has shown the customer a particular automobile.

S: (as he walks in and takes his seat) WELL, YOU'VE SEEN THE NEW FORD TAURUS 2 DOOR SPORT COUPE, YOU'VE DRIVEN IT AND NOW YOU'RE THE JUDGE. WHAT DO YOU THINK OF IT IN TERMS OF STYLE AND PERFORMANCE.

C: I REALLY LIKE THE STYLE BUT I'M NOT QUITE SURE ABOUT THE PERFORMANCE.

S: JUST WHAT IS IT ABOUT THE PERFORMANCE THAT YOU'RE NOT COMFORTABLE WITH? YOU'VE TOLD ME THAT YOU HAVE A VERY BUSY SCHEDULE AND YOU DO ALOT OF DRIVING. IT SEEMS THAT IT IS EXTREMELY IMPORTANT THAT THE CAR YOU DECIDE TO PURCHASE PERFORM WELL.

C: IT SEEMED TO BE JUST A LITTLE TOO SLUGGISH ON THE HIGHWAY.

S: IF YOU SAY SO. AS I MENTIONED EARLIER, THE PARTICULAR CAR THAT YOU DROVE TODAY HAS A 2300 CUBIC CENTIMETER, 4 CYLINDER ENGINE. WHAT MAY SUIT YOUR NEEDS BETTER WOULD BE THE 6 CYLINDER ENGINE WHICH IS AVAILABLE IN EITHER THE 200 OR 250 CUBIC INCH SIZE.

C: HOW MUCH BETTER ON GAS MILEAGE IS THE SMALLER ENGINE?

S: THE 4 CYLINDER ENGINE AVERAGES 25 MILES PER GALLON AS TESTED BY THE ENVIRONMENTAL PROTECTION AGENCY AND THE 6 CYLINDER ENGINE AVERAGES 21 MILES PER GALLON. A 4 MILE PER GALLON DIFFERENCE ISN'T A LOT IF YOU DON'T DO MUCH DRIVING ON A DAILY BASIS. BUT YOU HAVE TO KEEP IN MIND THAT YOU'VE INDICATED THAT ON SOME DAYS YOU DRIVE UP TO 200 MILES. THAT'S 50 GALLONS MORE A DAY THAT YOU WOULD CONSUME WITH THE 6 CYLINDER. ON THE OTHER HAND, YOU INDICATE THAT YOUR TIME IS VERY VALUABLE. IF THAT IS THE CASE THEN YOU CAN'T AFFORD TO DRIVE A SLUGGISH VEHICLE.

C: I GUESS YOU'RE RIGHT.

S: I KNOW I'M RIGHT. NOW, IF WE WERE TO ORDER THE 6 CYLINDER MODEL I WILL HAVE IT AVAILABLE HERE IN SIX WEEKS.

C: IF I DO DECIDE TO ORDER RATHER THAN TO GO WITH THE SHOWROOM MODEL WOULD I HAVE MY CHOICE OF INTERIORS?

S: YES, THAT'S ANOTHER ADVANTAGE TO ORDERING ! YOU CAN CHOOSE FROM STANDARD INTERIORS OF VINYL OR CLOTH; OR FROM 
OPTIONAL INTERIORS OF LEATHER OR VELOUR. THE LEATHER OR VELOUR WILL COST AN ADDITIONAL \$375. HERE IS A COLOR CHART. BOTH THE STANDARD AND THE OPTIONAL TRIMS ARE AVAILABLE IN ANY OF THESE COLORS. SPEAKING OF COLORS, YOU CAN ALSO CHOOSE YOUR EXTERIOR PAINT COLOR FROM THIS CHART. THE WHITE, RED, BLUE AND GREEN ARE AVAILABLE IN A METALLIC AS WELL AS A FLAT COLOR.

C: I'M RATHER INDIFFERENT TO COLOR SO I'M NOT TOO CONCERNED ABOUT THAT NOW.

S: RIGHT, WE CAN TAKE CARE OF THAT LATER. AS I TOLD YOU EARLIER, THE PRICE OF THE FLOOR MODEL IS $\$ 11,000$. IF YOU WERE TO ORDER THE 6 CYLINDER MODEL, THE FINAL PRICE WOULD BE... (salesperson pauses to calculate some figures)

$\$ 11,387$. IF YOU WERE TO ORDER THE OPTIONAL INTERIOR \$375. EXTRA FOR THE INTERIOR AND THE ADDITIONAL \$12. REFLECTS AN INCREASE IN TRANSPORTATION CHARGES. HOW WOULD YOU WANT TO PAY FOR THIS ?

C: I'D PROBABLY FINANCE AT LEAST SOME OF IT.

S: I'D NEED TO KNOW EXACTLY HOW MUCH YOU'D WANT TO FINANCE BUT IF YOU WERE TO DO IT THROUGH OUR COMPANY WE WOULD OFFER YOU AN ANNUAL PERCENTAGE RATE OF 11\% WITH A 20\% DOWN PAYMENT SO THIS RATE WOULD REQUIRE A DOWN PAYMENT OF \$2200.00. IF YOU WERE TO PLACE A DEPOSIT OF LESS THAN THIS AMOUNT, THE PERCENTAGE RATE WOULD BE $12 \%$.

C: (as he takes notes) IT SOUNDS REASONABLE TO ME, I'LL NEED A FEW DAYS TO THINK THIS OVER AND I'LL GET BACK TO YOU.

S: WELL, IF I DON'T HEAR FROM YOU WITHIN A WEEK, I'LL GIVE YOU A CALL. SHOULD I CALL DURING THE DAY OR AT NIGHT?

c: (standing up to leave and shaking hands with S) I'LL BE HOME AFTER 6:00. THANK YOU FOR YOUR TIME. 
LOW PRECISE/LOW FRIENDLY 
Scenario: Salesperson (S) and customer (C) enter the picture and sit across from each other at a desk. They have just left the showroom floor where the salesperson has shown the customer a particular automobile.

S: WELL JOHN, YOU'VE SEEN THE CAR, YOU'VE DRIVEN IT AND NOW YOU'RE THE JUDGE. WHAT DO YOU THINK OF IT IN TERMS OF STYLE AND PERFORMANCE?

C: I REALLY LIKE THE STYLE BUT I'M NOT QUITE SURE ABOUT THE PERFORMANCE.

S: I SEE. WHAT IS IT ABOUT THE PERFORMANCE THAT YOU DIDN'T LIKE?

C: IT SEEMED TO BE JUST A LITTLE TOO SLUGGISH ON THE HIGHWAY.

S: YOU KNOW WHAT YOUR NEEDS ARE BETTER THAN I DO AND YOU'RE THE ONE WHO WILL BE DRIVING THE CAR. AS I MENTIONED EARLIER, THE PARTICULAR CAR THAT YOU DROVE TODAY HAS SMALL ENGINE. WHAT MAY SUIT YOUR NEEDS BETTER WOULD BE THE 6 CYLINDER ENGINE.

C: HOW MUCH BETTER ON GAS MILEAGE IS THE SMALLER ENGINE?

S: I THINK THAT THE 4 CYLINDER ENGINE AVERAGES ABOUT 4 MILES PER GALLON MORE THAN THE 6 CYLINDER ENGINE. BUT YOU HAVE TOLD ME THAT ON SOME DAYS YOU DO A LOT OF DRIVING. ON THE OTHER HAND, YOU SAY THAT YOUR TIME IS SO VALUABLE THAT YOU CAN'T AFFORD TO DRIVE A SLUGGISH VEHICLE.

C: I GUESS YOU'RE RIGHT.

S: I KNOW I'M RIGHT, FROM WHAT YOU'VE TOLD ME, YOU HAVE DONE SO MUCH FOR YOUR COMPANY THAT NO ONE ELSE COULD EVEN COME CLOSE TO REACHING YOUR PRODUCTIVITY LEVEL.

C: IF I WERE TO ORDER THE 6 CYLINDER MODEL, WHEN WOULD IT $\mathrm{BE}$ IN?

S: I THINK IT SHOULD BE HERE IN SIX TO EIGHT WEEKS.

C: IF I DO DECIDE TO ORDER RATHER THAN TO GO WITH THE SHOWROOM MODEL WOULD I HAVE MY CHOICE OF INTERIORS?

S: YES, THERE'S ANOTHER ADVANTAGE TO ORDERING ! YOU CAN CHOOSE FROM THREE OR FOUR INTERIORS, SOME OF WHHCH COST EXTRA. HERE IS A COS COLOR CHART. 
C: I'M RATHER INDIFFERENT TO COLOR SO I'M NOT TOO CONCERNED ABOUT THAT NOW.

S: RIGHT, WE CAN TAKE CARE OF THAT LATER. AS I TOLD YOU EARLIER, THE PRICE OF THE CAR IS ABOUT \$11,000. IF YOU WERE TO ORDER THE 6 CYLINDER MODEL, THE FINAL PRICE WOULD BE HIGHER. HOW WOULD YOU WANT TO PAY FOR THIS ?

C: I'D PROBABLY FINANCE AT LEAST SOME OF IT.

S: IF YOU WERE TO DO IT THROUGH OUR COMPANY WE WOULD OFFER YOU A LOWER ANNUAL PERCENTAGE RATE WITH A 20\% DOWN PAYMENT THAN IF YOUR DOWN PAYMENT WERE LOWER.

C: (as he takes notes) IT SOUNDS REASONABLE TO ME, I'LL NEED A FEW DAYS TO THINK THIS OVER AND I'LL GET BACK TO YOU.

S: OF COURSE, YOU CAN GIVE ME A CALL IF YOU HAVE ANY ADDITIONAL QUESTIONS.

C: IF I DECIDED TO FINANCE THROUGH MY OWN BANK, WOULD THAT BE A PROBLEM?

S: NO, THAT SHOULDN'T BE A PROBLEM. JUST HAVE THE BANK CALL ME SO THAT WE CAN INITIATE THE PAPERWORK.

c: ( standing up to leave and shaking hands with S) THANK YOU FOR YOUR TIME. 


\section{LOW PRECISE/HIGH FRIENDLY}

The friendly communicator readily expresses admiration for others. They habitually acknowledge verbally other's constributions. Whenever they communicate they tend to be very encouraging to people. 
Scenario: Salesperson (S) and customer (C) enter the picture and sit across from each other at a desk. They have just left the showroom floor where the salesperson has shown the customer a particular automobile.

S: (as he walks in, he pats $C$ on back and takes his seat) WELL JOHN, YOU'VE SEEN THE CAR, YOU'VE DRIVEN IT AND NOW YOU'RE THE JUDGE. WHAT DO YOU THINK OF IT IN TERMS OF STYLE AND PERFORMANCE?

C: I REALLY LIKE THE STYLE BUT I'M NOT QUITE SURE ABOUT THE PERFORMANCE.

S: I SEE. WITH YOUR BUSY SCHEDULE AND THE AMOUNT OF DRIVING THAT YOU DO, IT IS EXTREMELY IMPORTANT THAT THE CAR YOU DECIDE TO PURCHASE PERFORM WELL.

C: IT SEEMED TO BE JUST A LITTLE TOO SLUGGISH ON THE HIGHWAY.

S: YOU KNOW WHAT YOUR NEEDS ARE BETTER THAN I DO AND YOU CAN EVALUATE WHAT'S AVAILABLE AS WELL AS I CAN. AS I MENTIONED EARLIER, THE PARTICULAR CAR THAT YOU DROVE TODAY HAS SMALL ENGINE. WHAT MAY SUIT YOUR NEEDS BETTER WOULD BE THE 6 CYLINDER ENGINE.

C: HOW MUCH BETTER ON GAS MILEAGE IS THE SMALLER ENGINE?

S: I THINK THAT THE 4 CYLINDER ENGINE AVERAGES ABOUT 4 MILES PER GALLON MORE THAN THE 6 CYLINDER ENGINE. BUT YOU HAVE TO KEEP IN MIND, JOHN, THAT YOU'VE INDICATED THAT ON SOME DAYS YOU DO A LOT OF DRIVING. ON THE OTHER HAND, YOUR TIME IS SO VALUABLE THAT YOU..OR I SHOULD SAY YOUR COMPANY CAN'T AFFORD FOR YOU TO DRIVE A SLUGGISH VEHICLE.

C: (half-smiling) I GUESS YOU'RE RIGHT.

S: I KNOW I'M RIGHT, FROM WHAT YOU'VE TOLD ME, YOU HAVE DONE SO MUCH FOR YOUR COMPANY THAT NO ONE ELSE COULD EVEN COME CLOSE TO REACHING YOUR PRODUCTIVITY LEVEL. YOU DESERVE TO BE PROUD OF YOURSELF, JOHN.

C: THANKS. IF I WERE TO ORDER THE 6 CYLINDER MODEL, WHEN WOULD IT BE IN?

S: I THINK IT SHOULD BE HERE IN SIX TO EIGHT NEEKS.

C: IF I DO DECIDE TO ORDER RATHER THAN TO GO WITH THE SHOWROOM MODEL WOULD I HAVE MY CHOICE OF INTERIORS?

S: YES, THERE'S ANOTHERR ADVANTAGE TO ORDERING ! I KNOW 
THAT YOUR CARS ARE ALWAYS AS WELL-COORDINATED AS YOU ARE. YOU CAN CHOOSE FROM THREE OR FOUR INTERIORS, SOME OF WHICH COST EXTRA. HERE IS A COLOR CHART.

C: I'M RATHER INDIFFERENT TO COLOR SO I'M NOT TOO CONCERNED ABOUT THAT NOW.

S: RIGHT, WE CAN TAKE CARE OF THAT LATER. AS I TOLD YOU EARLIER, THE PRICE OF THE CAR IS ABOUT $\$ 11,000$. IF YOU WERE TO ORDER THE 6 CYLINDER MODEL, THE FINAL PRICE WOULD BE HIGHER. HOW WOULD YOU WANT TO PAY FOR THIS JOHN?

C: I'D PROBABLY FINANCE AT LEAST SOME OF IT.

S: IF YOU WERE TO DO IT THROUGH OUR COMPANY WE WOULD OFFER YOU A LOWER ANNUAL PERCENTAGE RATE WITH A 20\% DOWN PAYMENT THAN IF YOUR DOWN PAYMENT WERE LOWER. YOU KNOW I'LL DO MY WHAT I CAN, JOHN, TO GET YOU THE BEST RATE I CAN.

C: (as he takes notes) IT SOUNDS REASONABLE TO ME, I'LI NEED A FEW DAYS TO THINK THIS OVER AND I'LL GET BACK TO YOU.

S: OF COURSE, YOU SHOULD THINK ABOUT IT. IT'S IMPORTANT THAT YOU ARE COMFORTABLE WITH THE DECISION. DON'T HESITATE TO CALL IF YOU HAVE ANY ADDITIONAL QUESTIONS. ALSO, IF YOU DECIDE NOT TO FINANCE THROUGH US, I'D BE HAPPY TO MAKE THE NECESSARY ARRANGEMENTS FOR YOU THROUGH THE BANK OF YOUR CHOICE.

C: ( standing up to leave and shaking hands with S) THANK YOU FOR YOUR TIME. 
HIGH PRECISE/HIGH FRIENDLY

The precise communicator insists that other people document or present some kind of proof for what they are arguing. They like to be strictly accurate when they communicate. In arguments they insist upon very precise definitions.

The friendly communicator readily expresses admiration for others. They habitually acknowledge verbally other's constributions. Whenever they communicate they tend to be very encouraging to people. 
Scenario: Salesperson (S) and customer (C) enter the picture and sit across from each other at a desk. They have just left the showroom floor where the salesperson has shown the customer a particular automobile.

S: (as he walks in, he pats $C$ on back and takes his seat) WELL JOHN, YOU'VE SEEN THE NEW FORD TAURUS 2 DOOR SPORT COUPE, YOU'VE DRIVEN IT AND NOW YOU'RE THE JUDGE. WHAT DO YOU THINK OF IT IN TERMS OF STYLE AND PERFORMANCE.

C: I REALLY LIKE THE STYLE BUT I'M NOT QUITE SURE ABOUT THE PERFORMANCE.

S: JUST WHAT IS IT ABOUT THE PERFORMANCE THAT YOU'RE NOT COMFORTABLE WITH? WITH YOUR BUSY SCHEDULE AND THE AMOUNT OF DRIVING THAT YOU DO, IT IS EXTREMELY IMPORTANT THAT THE CAR YOU DECIDE TO PURCHASE PERFORM WELL.

C: IT SEEMED TO BE JUST A LITTLE TOO SLUGGISH ON THE HIGHWAY .

S: YOU KNOW WHAT YOUR NEEDS ARE BETTER THAN I DO AND YOU CAN EVALUATE WHAT'S AVAILABLE AS WELL AS I CAN. AS I MENTIONED EARLIER, THE PARTICULAR CAR THAT YOU DROVE TODAY HAS A 2300 CUBIC CENTIMETER, 4 CYLINDER ENGINE. WHAT MAY SUIT YOUR NEEDS BETTER WOULD BE THE 6 CYLINDER ENGINE WHICH IS AVAILABLE IN EITHER THE 200 OR 250 CUBIC INCH SIZE.

C: HOW MUCH BETTER ON GAS MILEAGE IS THE SMALLER ENGINE?

S: THE 4 CYLINDER ENGINE AVERAGES 25 MILES PER GALLON AS TESTED BY THE ENVIRONMENTAL PROTECTION AGENCY AND THE 6 CYLINDER ENGINE AVERAGES 21 MILES PER GALLON. A 4 MILE PER GALLON DIFFERENCE ISN'T A LOT IF YOU DON'T DO MUCH DRIVING ON A DAILY BASIS. BUT YOU HAVE TO KEEP IN MIND, JOHN, THAT YOU'VE INDICATED THAT ON SOME DAYS YOU DRIVE UP TO 200 MILES. THAT'S 50 GALLONS MORE A DAY THAT YOU WOULD CONSUME WITH THE 6 CYLINDER. ON THE OTHER HAND, YOUR TIME IS SO VALUABLE THAT YOU..OR I SHOULD SAY YOUR COMPANY CAN'T AFFORD FOR YOU TO DRIVE A SLUGGISH VEHICLE.

C: (half-smiling) I GUESS YOU'RE RIGHT.

S: I KNOW I'M RIGHT, FROM WHAT YOU'VE TOLD ME, YOU HAVE DONE SO MUCH FOR YOUR COMPANY THAT NO ONE ELSE COULD EVEN COME CLOSE TO REACHING YOUR PRODUCTIVITY LEVEL. YOU DESERVE TO BE PROUD OF YOURSELF, JOHN.

C: THANKS. 
S: NOW, IF WE WERE TO ORDER THE 6 CYLINDER MODEL I WILL HAVE IT AVAILABLE HERE IN SIX WEEKS.

C: IF I DO DECIDE TO ORDER RATHER THAN TO GO WITH THE SHOWROOM MODEL WOULD I HAVE MY CHOICE OF INTERIORS?

S: YES, THERE'S ANOTHER ADVANTAGE TO ORDERING ! I KNOW THAT YOUR CARS ARE ALWAYS AS WELL-COORDINATED AS YOU ARE. YOU CAN CHOOSE FROM STANDARD INTERIORS OF VINYL OR CLOTH; OR FROM OPTIONAL INTERIORS OF LEATHER OR VELOUR. THE LEATHER OR VELOUR WILL COST AN ADDITIONAL \$375. HERE IS A COLOR CHART. BOTH THE STANDARD AND THE OPTIONAL TRIMS ARE AVAILABLE IN ANY OF THESE COLORS. SPEAKING OF COLORS, YOU CAN ALSO CHOOSE YOUR EXTERIOR PAINT COLOR FROM THIS CHART. THE WHITE, RED, BLUE AND GREEN ARE AVAILABLE IN A METALLIC AS WELL AS A FLAT COLOR.

C: I'M RATHER INDIFFERENT TO COLOR SO I'M NOT TOO CONCERNED ABOUT THAT NOW.

S: RIGHT, WE CAN TAKE CARE OF THAT LATER. AS I TOLD YOU EARLIER, THE PRICE OF THE FLOOR MODEL IS $\$ 11,000$. IF YOU WERE TO ORDER THE 6 CYLINDER MODEL, THE FINAL PRICE WOULD BE... (salesperson pauses to calculate some figures)

$\$ 11,387$. IF YOU WERE TO ORDER THE OPTIONAL INTERIOR \$375. EXTRA FOR THE INTERIOR AND THE ADDITIONAL \$12. REFLECTS AN INCREASE IN TRANSPORTATION CHARGES. HOW WOULD YOU WANT TO PAY FOR. THIS JOHN?

C: I'D PROBABLY FINANCE AT LEAST SOME OF IT.

S: I'D NEED TO KNOW EXACTLY HOW MUCH YOU'D WANT TO FINANCE BUT IF YOU WERE TO DO IT THROUGH OUR COMPANY WE WOULD OFFER YOU AN ANNUAL PERCENTAGE RATE OF 11\% WITH A 20\% DOWN PAYMENT SO THIS RATE WOULD REQUIRE A DOWN PAYMENT OF \$2200.00. IF YOU WERE TO PLACE A DEPOSIT OF LESS THAN THIS AMOUNT, THE PERCENTAGE RATE WOULD BE $12 \%$.

C: (as he takes notes) IT SOUNDS REASONABLE TO ME, I'LI NEED A FEW DAYS TO THINK THIS OVER AND I'LL GET BACK TO YOU.

S: OF COURSE, YOU SHOULD THINK ABOUT IT. IF I DON'T HEAR FROM YOU WITHIN A WEEK, I'LL GIVE YOU A CALL TO ANSWER ANY ADDITIONAL QUESTIONS WHICH YOU MIGHT HAVE ABOUT THE CAR OR ABOUT THE FINANCE PROGRAM. IF YOU DECIDE NOT TO FINANCE THROUGH US, I'D BE HAPPY TO MAKE THE NECESSARY ARRANGEMENTS FOR YOU THROUGH THE BANK OF YOUR CHOICE.

C: (standing up to leave and shaking hands with S) THANK YOU FOR YOUR TIME. 
APPENDI: D

LAB STUDY QUESTIONNAIRE 
PLEASE PROVIDE THE FOLLOWING INFORMATION:

Age :

Sex: M F (circle one)

Year: Freshman Sophmore Junior senior (circle one)

Major:

How many cars have you purchased on your own?

Have you ever held a position in sales? yes no (circle one)

YOU HAVE JUST BEEN SHOWN A VIDEOTAPE DEPICTING AN INTERACTION BETWEEN A SALESPERSON AND A CUSTOMER. IN WHAT FOLLOWS, WE ARE TRYING TO OBTAIN YOUR TRUE REACTIONS TO WHAT YOU HAVE JUST SEEN. PLEASE READ EACH STATEMENT CAREFULIY BEFORE CHECKING THE CATEGORY THAT BEST DESCRIBES YOUR REACTIONS. 
PLEASE PLACE A CHECKMARK ON EACH OE THE SCALES BELOW AT THAT PLACE WHICH BEST REELECIS YOLR REACTIONS.

1. Salespeople are basically deceptive.



2. This salespetson was animated.

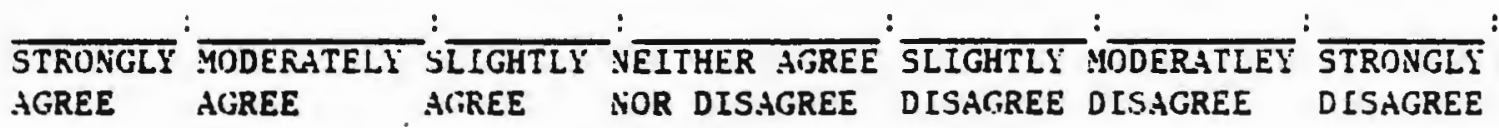

3. This salespersun was bonest.

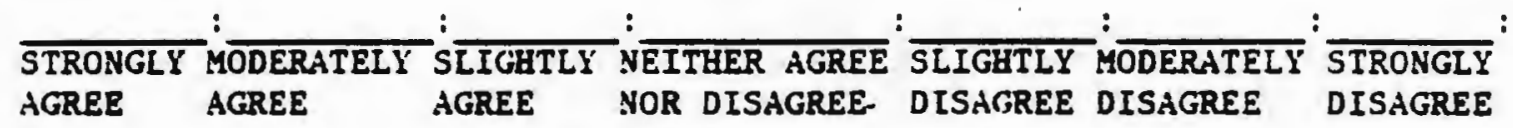

4. This salesperson was an effective communicator.

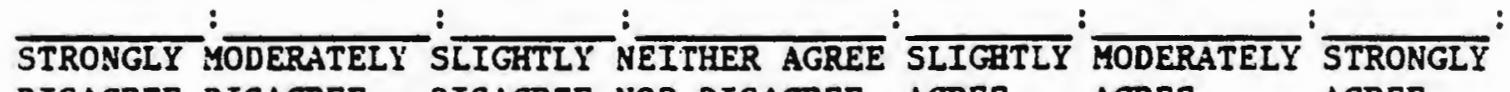
DISAGREE DISAGREE DISAGREE NOR DISAGREE AGREE AGREE AGREE

5. The inceraction between the salesperson and the customer was friendly.

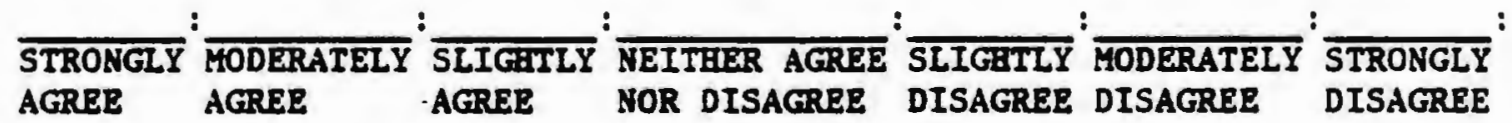

6. This salesperson was relaxed.

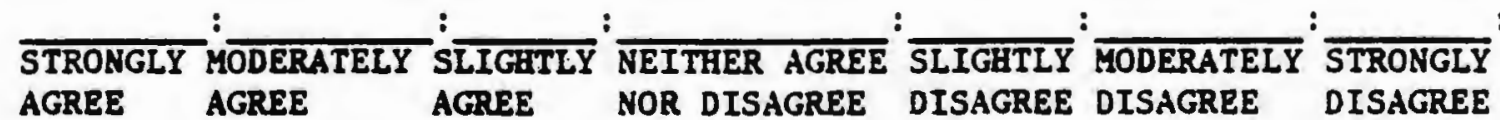

7. This salesperson was dramatic.

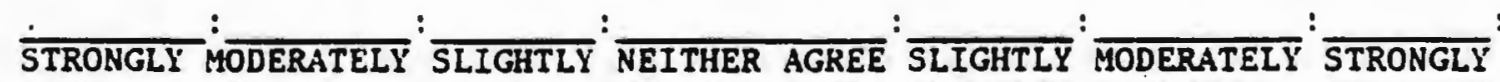
AGREE AGREE AGREE NOR DISAGREE DISAGREE DISAGREE DISAGREE 
8. This salesperson was precise.

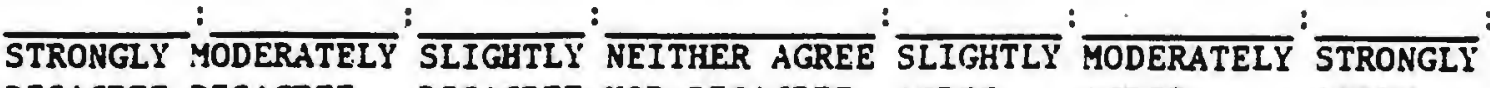
DISAGREE DISAGREE DISAGREE NOR DISAGREE AGREE AGREE AGREE

9. This salesperson was friendly.

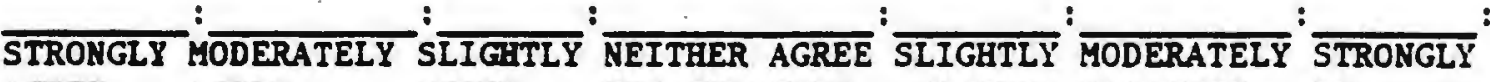
AGREE AGREE AGREE NOR DISAGREE DISAGREE DISAGREE DISAGREE

10. This salesperson was opea.

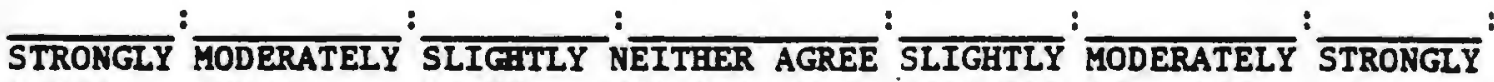
AGREE AGREE AGRER NOR DISAGREE DISAGREE DISAGREE DISAGREE

11. This salesperson was contentious.

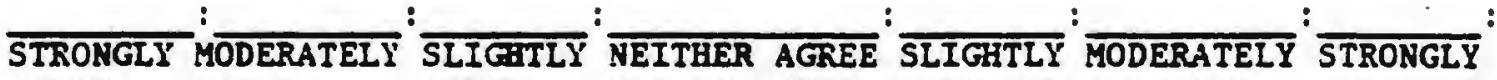
AGREE AGREE AGREE NOR DISAGREE DISAGREE DISAGREE DISAGREE

12. This salesperson was doninant.

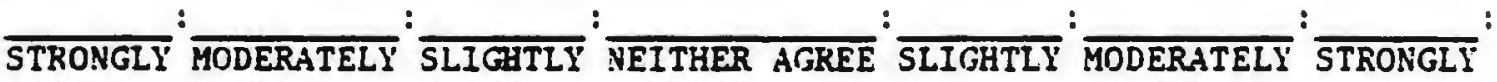
AGREE AGREE AGREE NOR DISAGREE DISAGREE DISAGREE DISAGREE

13. The salesperson in the tape was impression leaving.

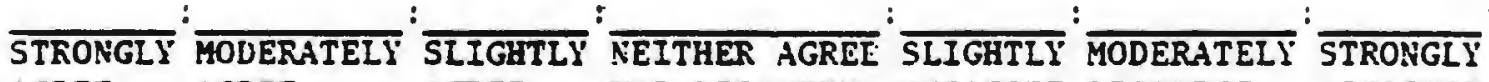
AGREE AGREE AGREE NOR DISAGREE NISAGREE DISAGREE IISAGREE

14. This salesferson was attentive.

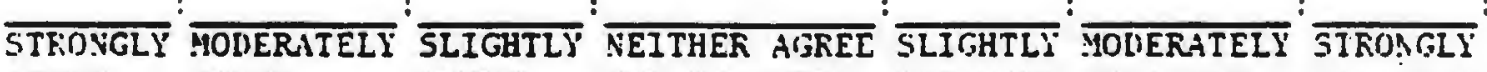
AGREE AGREE AGREE NOR DISAGREE DISAGREE DIGAGREE DISAGREE

15. The salespetson in the tape had a good sommunicatior image.

STKONGLY' AGREE AGREE AGREE NOR DISAGREE DISAGREE IIISAGREE DISAGREE

16. The salespersun in the cape was a strong cirmunicacor.

STRONGLY MODERATEIY SLIGHTLY NEITHEK AGREE $\overline{\text { SLIGHTLY MODERATEIY }}{ }^{\prime}$ STRONGLY AGREE AGREE AGREE NOR DISAGREE DISAGREE DISAGREE DISAGREE 
17. The salespersion in the cape hat a gentle appriach

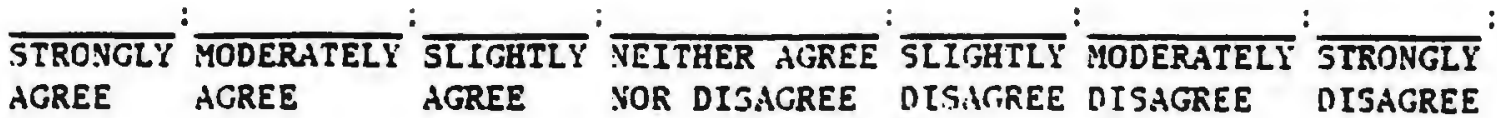

18. Salespeople are usually helpful.

STROYGLY $: \overline{\text { MODERATELI }}: \frac{}{\text { SLIGITLY }}$ : DI'S.ITREE OISIGREE CLS.IGREE HOR DIGAGREE AGRFE ACREE AGRE

19. I always shop for the lowest price prontuct availatile.

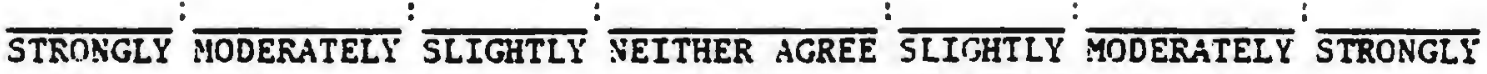
AGREE AGREE AGREE HOR DISAGREE DISAGREE DISAGREE DISAGREE

20. When purchasing high ticket items. I value a salesperson's opinion.

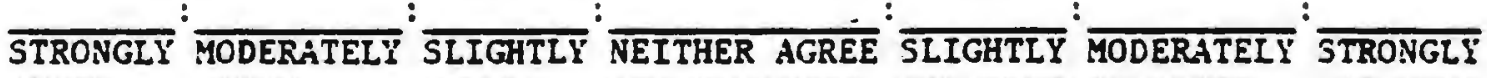
AGREE AGREE AGREE NOR DISAGREE DISAGREE DISAGREE DISAGREE

21. I like a salesperson who tells me a lot about a product even if I don't ask for the information.

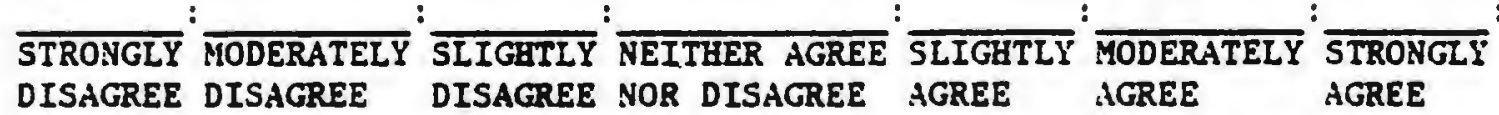
22. I like a salesperson who engages in general conversation.


23. This salesperson tended to monopolize the conversation.

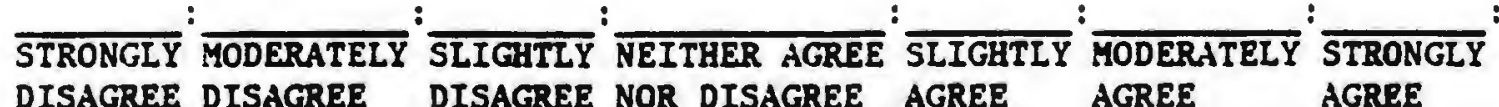
24. The liklihood that the customer in the cape bought the product is.

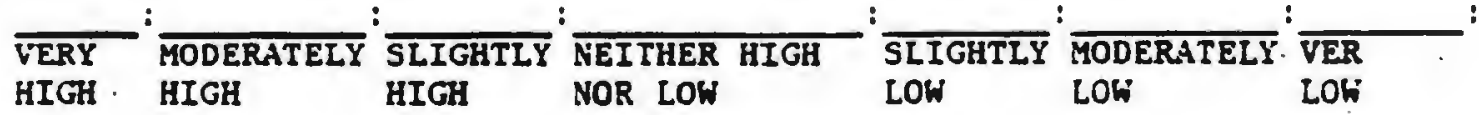


33. I like when a salesperson takes a personal interest in ae.

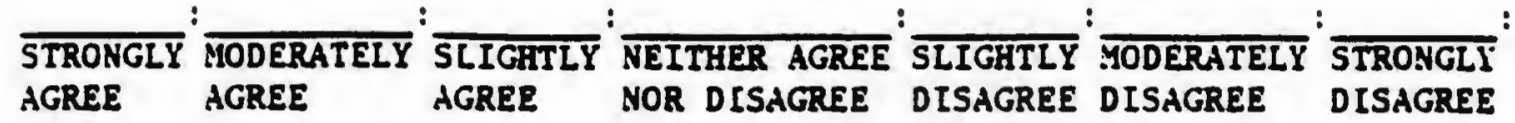

34. I prefer not to have a salesperson help me in evaluating a product.



35. The salesperson in the tape was exact.

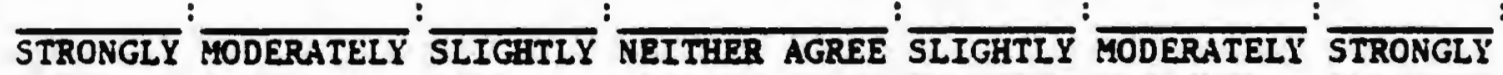
AGREE AGREE AGRE NOR DISAGREE DISAGREE DISAGREE DISAGREE

36. I like when a salesperson pays se compliments.

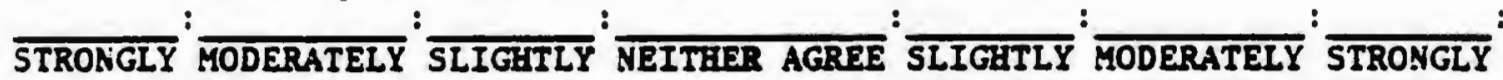
AGREE AGREE AGREE NOR DISAGREE DISAGREE DISAGREE DISAGREE

37. The sales activity involved between selling a car and selling a house are:

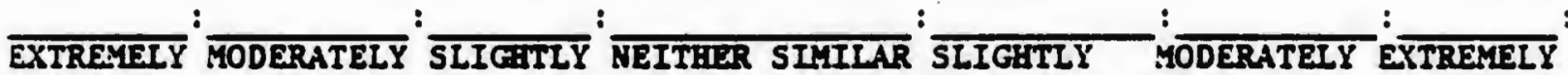
SIMILLR SIMILAR SIMILAR MOR DISSIMILAR DISSIMTLAR DISSIMILAR DISSIMILAR

38. The sales activity involved between selling a car and selling a dianond ring are:

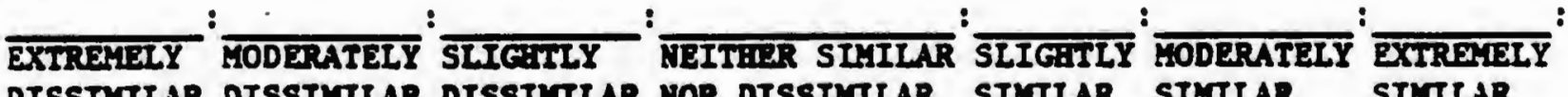
DISSIMILAR DISSIMILAR DISSIMIILAR MOR DISSIMILAR SIMIIAR SIMILAR SIMILAR

39. The sales activity involved between selling a house and selling a boat are:

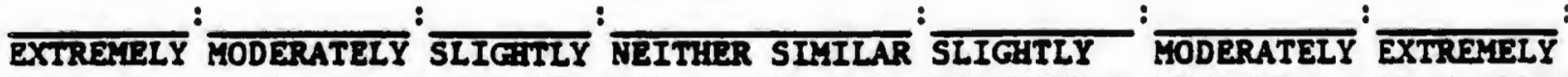
SIMILAR SIMILAR. SIMILAR NOR DISSIMILAR DISSIMILAR DISSIMILAR DISSIMILAR

40. The sales activity involved between selling a car and selling a boat are:

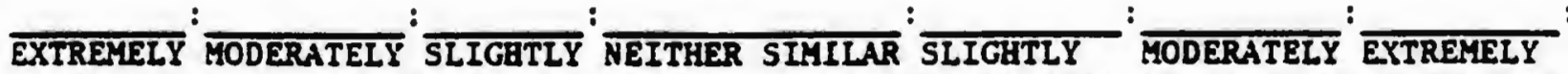
SIMILAR SIMILAR SIMILAR NOR DISSIMILAR DISSIMTLAR DISSIMILAR DISSIMILAR 


\section{BIBLIOGRAPHY}

Bass, B.M. (1960). Leadership, Psychology, and organizational Behavior. New York: Harper Bros.

Bass, B.M. (1967). Social behavior and the orientation inventory: A review. Psychological Bulletin, 68, 260-92.

Bednar, D.A. (1982). Relationships between communicator style and managerial performance in complex organizations: a field study. Journal of Business Communicantion, 19, 51-75.

Capon, N., Holbrook, M.B., \& Hulbert, J.M. (1977). Selling process and buyer behavior: Theoretical implications of recent research. In A.G. Woodside, J.N. Sheth \& P.D. Bennett (eds), Consumer and Industrial Buying Behavior. New York: Elsevier North Holland, Inc.

Churchill, G., Ford, N., \& Walker, O. (1985). Sales Force Management. Homewood, IL.: Richard D. Irwin, Inc.

Churchill, G., Ford, N., Hartley, S. \& Walker, O. (1985). The determinants of salesperson performance: A metaanalysis. Journal of Marketing Research, 22, 103-18.

Crowne, D.P. \& Marlowe, D. (1960). A new scale of social desirability independent of psychopathology. Journal of Consulting Psychology, 24(4), 349-54.

Emery, D., Norton, R., \& Plain, H. (1980). Relaxed as a style ofcommunicating. Paper presented at the annual meeting of theInternation Communication Association, Acapulco, Mexico.

Friedman, M., \& Churchill, G.A., (1987). Using consumer perspectives and a contingency approach to improve health care delivery. Journal of consumer Research, 13, 492-510.

Graetz, H.G. (1974). Verbal Behavior and Managerial Effectiveness of Supermarket store Managers. Unpublished D.B.A. Dissertation, Harvard University, Cambridge, Ma.

Norton, R. (1977). Teacher effectiveness as a function of communicator style. In B.D. Ruben (ed.), Communication Yearbook I. New Brunswick: Transaction Books.

Norton, R. (1978). Foundation of a communicator style construct. Human Communication Research, 4 99-112. 84 
Norton, R. (1983). Communicator Style: Theory, application and measures. Beverly Hills, CA: Sage Publications.

Norton, R., Baker, N., Bednar, D., Sayler, R., \& McGough, T. (1978). Impressions of interpersonal dramatic style. Paper presented at the annual meeting of the speech Communication Association, Minneapolis, Mi.

Norton, R. \& Bednar, D.A., (1979). Ideal communicator style for the interviewee. Paper presented at the annual meeting of the International Communication Association, Philadelphia, Pa.

Norton, R., \& Miller, L. (1975). Dyadic perception of communication style. Communication Research, 2 50-67.

Norton, R., \& Montgomery, B. (1979). An integration of style, content, and target in defining and measuring openness. Paper presented at the annual meeting of the International Communication Àssociation, Philadelphia, Pa.

Norton, R., \& Nussbaum, J. (1980). Dramatic behaviors of the effective teacher. In Nimmo, D. (ed.) Communication Yearbook. 4 New Brunswick: Transaction Books.

Norton, R., \& Pettegrew, L.S. (1977). Communicator style as an effect determinant of attraction. Communication Research, 4, 257-82.

Norton, R., \& Robinson, D. Communicator style in career decisions. Paper presented at the annual meeting of the Speech Communication Association. New York.

Norton, R., Syphner, H., Clarke, C., \& Brady. (1977). Dimensions of a dramatic communicator style. Paper presented at the annual meeting of the speech Communication Association, washington, DC.

Notarantonio, E.M. \& Cohen, J.L. (1988). The effects of open and dominant communication styles on perceptions of the sales interaction. Journal of Personal selling and Sales Management. Under editorial review.

Pace, W.R. (1962). Oral communication and sales effectiveness. Journal of Applied Psychology, 44, 487-8. 
Sheth, J.M. (1976). Buyer-seller interaction: A conceptual framework. Proceedings of the Association for Consumer Research. Cincinnati, OH: Association for Consumer Research, 382-6.

Staley, C.C., \& Cohen, J.L. (1988). Communicator style and social style: similarities and differences between the sexes. Communication ouarterly. 36, 192-202.

Szymanski, David M. (1988). Determinants of selling effectiveness: The importance of declarative knowledge to the personal selling concept. Journal of Marketing, 52, 64-77.

Ward, J. H. (1963). Hierarchical grouping to optimize an objective function. Journal of American Statistical Association, 58, 236-244.

Weitz, Barton A. (1981). Effectiveness in sales interactions: a contingency framework. Journal of Marketing, 45, 85$103 .$.

Weitz, B., Sujan, H., \& Sujan, M. (1986). Knowledge, motivation, and adaptive behavior: A framework for improving selling effectiveness. Journal of Marketing, 50, 174-191.

Weitz, B.A., \& Wright, P. (1978). The salesperson as a marketing strategist: The relationship between field sales performance and insights about one's customers. MSI Working Paper No. 78-120, Marketing Science Institute.

Williams, K.C. \& Spiro, R.L. (1985). Communication style in the salesperson-customer dyad. Journal of Marketing Research. 22.434-42. 